\title{
Melatonin affects voltage-dependent calcium and potassium currents in MCF-7 cell line cultured either in growth or differentiation medium
}

\author{
Roberta Squecco ${ }^{a}$, Alessia Tani ${ }^{\text {b }}$, Sandra Zecchi-Orlandini ${ }^{\text {a }}$, \\ Lucia Formigli ${ }^{\mathrm{b}}$, Fabio Francini ${ }^{\mathrm{a}, *}$ \\ a Department of Experimental and Clinical Medicine, Section of Physiological Sciences, University of Florence, 50134 Florence, Italy \\ ${ }^{\mathrm{b}}$ Department of Experimental and Clinical Medicine, Section of Anatomy and Histology, University of Florence, 50134 Florence, Italy
}

\section{A R T I C L E I N F O}

\section{Article history:}

Received 24 November 2014

Received in revised form

24 March 2015

Accepted 25 March 2015

Available online 3 April 2015

\section{Keywords: \\ Melatonin}

Voltage-dependent $\mathrm{Ca}^{2+}$ currents

Voltage-dependent $\mathrm{K}^{+}$currents

Electrophysiology

Chemical compounds studied in this article: $\alpha$-Dendrotoxin (PubChem SID: 135651983)

Chromanol (PubChem CID: 92890)

Iberiotoxin (PubChem CID: 16132435)

Melatonin (PubChem CID: 896)

Nifedipine (PubChem CID: 4485)

\begin{abstract}
A B S T R A C T
Big efforts have been dedicated up to now to identify novel targets for cancer treatment. The peculiar biophysical profile and the atypical ionic channels activity shown by diverse types of human cancers suggest that ion channels may be possible targets in cancer therapy. Earlier studies have shown that melatonin exerts an oncostatic action on different tumors. In particular, it was shown that melatonin was able to inhibit growth/viability and proliferation, to reduce the invasiveness and metastatic properties of human estrogen-sensitive breast adenocarcinoma MCF-7 cell line cultured in growth medium, with substantial impairments of epidermal growth factor (EGF) and Notch-1-mediated signaling. The purpose of this work was to evaluate on MCF-7 cells the possible effects of melatonin on the biophysical features known to have a role in proliferation and differentiation, by using the patch-clamp technique. Our results show that in cells cultured in growth as well as in differentiation medium melatonin caused a hyperpolarization of resting membrane potential paralleled by significant changes of the inward $\mathrm{Ca}^{2+}$ currents ( $\mathrm{T}$ - and L-type), outward delayed rectifier $\mathrm{K}^{+}$currents and cell capacitance. All these effects are involved in MCF-7 growth and differentiation. These findings strongly suggest that melatonin, acting as a modulator of different voltage-dependent ion channels, might be considered a new promising tool for specifically disrupting cell viability and differentiation pathways in tumour cells with possible beneficial effects on cancer therapy.
\end{abstract}

(c) 2015 Elsevier B.V. All rights reserved.

\section{Introduction}

Conventional chemotherapy is not always successful and usually accompanied by systemic toxicity and detrimental side effects. Thus, growing attempts are made to identify novel targets for cancer therapy.

The diverse types of human cancers may show a peculiar biophysical profile with an atypical ion channels activity (Abdul et al., 2003; Arcangeli et al., 2009). In such perspective, it might be worth to better characterize this issue with the aim of designing efficient ionic channel inhibitors/modulators that may potentially affect cancer therapy. Functional relationship exists between resting

\footnotetext{
Abbreviations: $\alpha$-DTX, $\alpha$-dendrotoxin; Chr, chromanol; HP, holding potential; IbTx, iberiotoxin; $I_{\mathrm{BK}}$, voltage- and $\mathrm{Ca}^{2+}$-dependent delayed-rectifier iberiotoxinsensitive $\mathrm{K}^{+}$current; IKCa, intermediate-conductance $\mathrm{Ca}^{2+}$-activated $\mathrm{K}^{+}$channels; $I_{\mathrm{Ca}, \mathrm{L}}$, L-type $\mathrm{Ca}^{2+}$ current; $I_{\mathrm{Ca}, \mathrm{T}}, \mathrm{T}$-type $\mathrm{Ca}^{2+}$ current; $I_{\mathrm{Ks}}$, slowly activating chromanol-sensitive $\mathrm{K}^{+}$current; $I_{\mathrm{K}(\mathrm{V})}$, fast activating $\alpha$-dendrotoxin-sensitive $\mathrm{K}^{+}$ current; MLT, melatonin; MT1, melatonin receptor 1; MTS, 3-(4.5-dimethylthiazol2-yl)-5-(3-carboxymethoxyphenyl)-2-(4-sulfophenyl)-2Htetrazolium assay; RMP, resting membrane potential

* Corresponding author. Tel.: + 39055 2751629; fax: +39055 2751640.

E-mail address: fabio.francini@unifi.it (F. Francini).
}

membrane potential, $\mathrm{K}^{+}$channel type expression and cell functions such as proliferation and differentiation (Asher et al., 2010; Cos and Sánchez-Barceló, 2003; Enomoto et al., 1986; Wang, 2004). Resting membrane potential is typically more depolarized in undifferentiated respect to differentiated cells (O'Grady and Lee, 2005; Pardo, 2004) and in cancer cells respect to terminally differentiated cells (Kunzelmann, 2005). Of interest, resting membrane potential and the type and amount of $\mathrm{K}^{+}$and $\mathrm{Ca}^{2+}$ currents change during both cell cycle and differentiation (Blackiston et al., 2009; Sundelacruz et al., 2009) and are atypically modified in cancer cells (Becchetti, 2011; Bielanska et al., 2009; Haren et al., 2010; Lang et al., 2003; Ohkubo and Yamazaki, 2012; Ouadid-Ahidouch and Ahidouch, 2008).

By multidisciplinary approach, it was demonstrated on MCF-7 cell line (Margheri et al., 2012) that growth/viability and proliferation is significantly reduced by the treatment with melatonin, the hormone mostly produced by the pineal gland (Jablonska et al., 2013).

Moreover, preclinical in vitro and in vivo studies and clinical trials showed that melatonin was able to exert an oncostatic action on different tumors (Girgert et al., 2009; Hill et al., 2009, 2011a,b; Jung and Ahmad, 2006; Sánchez-Barceló et al., 2012; Srinivasan et al., 2008), to increase the efficacy of chemotherapy when used 
in adjuvant settings and to decrease the side effects (Vijayalaxmi et al., 2002). Since proliferation and differentiation are typical of any cell system and are carefully regulated in the course of physiological development and life cycle, tumor evolution must imply a deregulation of their morphofunctional features.

In the present study, we evaluated the electrophysiological properties and the effects of melatonin on MCF-7 cells cultured in either growth or differentiation medium focusing our attention on ion channels as possible novel targets involved in cancer pathophysiology. In particular, by electrophysiological technique, we evaluated the action of melatonin on resting membrane potential and on voltage-dependent ionic channels known to play a role in proliferation (Baglioni et al., 2012; Bertolesi et al., 2002; Currò, 2014; Enomoto et al., 1986; Gamper et al., 2002; Girgert et al., 2009; Grant et al., 2009; Gray et al., 2004; Haren et al., 2010; Kunzelmann, 2005).

The rationale for this research originates from the evidence that several ionic channels have a key role in proliferation and differentiation and can be therefore considered as new targets for cancer therapy (Arcangeli et al., 2009).

\section{Materials and methods}

\subsection{Cell culture and treatments}

Human hormone-sensitive breast adenocarcinoma cell line MCF-7 was obtained from American Type Culture Collection (ATCC, Manassas, VA, USA). The cells were cultured as previously described (Margheri et al., 2012). Briefly, cells were cultured in Dulbecco's modified Eagle's medium (DMEM, Sigma, Milan, Italy) supplemented with 10\% Fetal Bovine Serum (FBS, Sigma), $100 \mathrm{U} / \mathrm{mL}$ penicillin-streptomycin and $1 \%$ L-glutamine $200 \mathrm{mM}$ (Sigma) in a humidified $5 \% \mathrm{CO}_{2}$ atmosphere at $37{ }^{\circ} \mathrm{C}$. This medium was suitable to allow cells growth/proliferation. In all the experiments melatonin $100 \mu \mathrm{M}$ (Sigma) was used. This dose was proved to be the most effective to reduce cell viability and proliferation in this experimental model (Margheri et al., 2012). MCF-7 cells were cultured in growth medium in the presence of $100 \mu \mathrm{M}$ melatonin for $24,48,72 \mathrm{~h}$. In parallel experiments, the cells were cultured for $72 \mathrm{~h}$ in growth medium in the presence of melatonin and/or the following channel blockers (Sigma): nifedipine $(10 \mu \mathrm{M})$ and $\mathrm{NiCl}_{2}(50 \mu \mathrm{M})$ for $\mathrm{L}$ - and T-type $\mathrm{Ca}^{2+}$ channels; $\alpha$-dendrotoxin, $\alpha$-DTX $(10 \mathrm{nM})$ for $\mathrm{K}_{(\mathrm{V})}$, iberiotoxin, IbTx (100 nM) for BK and chromanol, Chr $(50 \mu \mathrm{M})$ for $\mathrm{K}_{\mathrm{s}}$ channels. The treatments lasted up to $72 \mathrm{~h}$ and the media were daily replaced. In other experiments the cells were cultured for $72 \mathrm{~h}$ in differentiation medium (supplemented with $2 \%$ FBS) and treated with channel blockers as above described.

\subsection{Cell growth/viability assay (MTS)}

Cell growth/viability was evaluated by 3-(4.5-dimethylthiazol-2yl)-5-(3-carboxymethoxyphenyl)-2-(4-sulfophenyl)-2Htetrazolium (MTS) assay (Promega, Madison, WI, USA). MCF-7 cells were plated into 96-multiwell-plates and then treated with melatonin $100 \mu \mathrm{M}$ and/or the above-mentioned channel blockers for $72 \mathrm{~h}$. Then, the cells were shifted in $100 \mu \mathrm{l}$ of fresh medium phenol red-free and $20 \mu \mathrm{l}$ of MTS test solution was added to each well. After $4 \mathrm{~h}$ of incubation, the color reaction was measured using a multi-well scanning spectrophotometer (Enzyme-Linked ImmunoSorbent Assay-ELISA- reader) (Amersham, Pharmacia Biotech, Cambridge, UK) at a wavelength of $490 \mathrm{~nm}$. The values were expressed as mean \pm S.D. obtained from five independent experiments carried out in triplicates.
In some experiments MCF-7 were treated with melatonin for $72 \mathrm{~h}$ in growth medium and, in a parallel set of experiments, in differentiation medium and treated with different channel blockers.

\subsection{Confocal immunofluorescence}

To detect proliferation activity, untreated and treated MCF-7 cells grown on glass coverslips were fixed with $0.5 \%$ buffered paraformaldehyde for $10 \mathrm{~min}$ at room temperature. After permeabilization with cold acetone for $3 \mathrm{~min}$, the fixed cells were blocked with $0.5 \%$ bovine serum albumin (BSA; Sigma) and 3\% glycerol in PBS for 20 min and then immunostained with rabbit polyclonal anti-Ki-67 (1:100; Abcam, Cambridge, UK). The immunoreaction was revealed by incubation with specific anti-rabbit Alexa Fluor 488-conjugated IgG (1:200; Molecular Probes, Eugene, OR, USA), for $1 \mathrm{~h}$ at room temperature. After washing in PBS, the sections were mounted with an anti-fade mounting medium (Biomeda Gel mount, Electron Microscopy Sciences, Foster City, CA, USA). A negative control was performed by replacing the primary antibody with non-immune mouse serum. Sections were examined with a Leica TCS SP5 confocal laser scanning microscope (Leica Microsystem, Mannheim, DE) equipped with a HeNe/Argon laser source for fluorescence measurements. Fluorescence was collected using a Leica PlanApo x63 oil-immersion objective. Optical sections $(1024 \times 1024$ pixels $)$ at intervals of $0.8 \mu \mathrm{m}$ were obtained and superimposed to create a single composite image. When needed, a single optical fluorescent section and DIC images were merged to view the precise distribution of the immunostaining. Quantification of Ki-67 expression was performed on digitized images by counting the number of positive cells over the total cell number.

\subsection{Confocal analysis of intracellular $\mathrm{Ca}^{2+}$ concentration}

The analysis of $\left[\mathrm{Ca}^{2+}\right]_{\mathrm{i}}$ was performed as previously reported (Formigli et al., 2002). Briefly, to reveal the resting intracellular calcium concentration in MCF-7 cells in the absence or presence of melatonin $(100 \mu \mathrm{M}), \sim 2 \times 10^{4}$ cells were plated on glass coverslips and incubated at $37^{\circ} \mathrm{C}$ for $10 \mathrm{~min}$ in DMEM with Fluo 3-acetoxymethyl ester (Molecular Probes) as fluorescent $\mathrm{Ca}^{2+}$ indicator at a final concentration of $10 \mu \mathrm{M}$ and $0.1 \%$ anhydrous dimethyl sulfoxide and Pluronic F-127 (0.01\% wt/vol) as dispersing agent (Molecular Probes). After being washed, the cells were placed in open slide flow-loading chambers mounted on the stage of the confocal laser scanning microscope. Optical sections $(1024 \times 1024$ pixels $)$ at intervals of $0.8 \mu \mathrm{m}$ were obtained. A variable number of cells ranging from 15 to 30 were analysed for each cell preparation. Multiple regions of interest (ROIs) of $25 \mu \mathrm{m}^{2}$ were selected within the cells to monitor $\mathrm{Ca}^{2+}$ signals, and outside the cells as baseline. Fluorescence signals were expressed as fractional changes above the resting baseline, $\Delta F / F$, where $F$ was the averaged baseline fluorescence and $\Delta F$ represented the fluorescence changes from the baseline.

\subsection{Electrophysiological experiments}

The electrophysiological characteristics of different voltagegated ionic channels of cultured MCF-7 were investigated on glass coverslip-adherent single cells at room temperature $\left(20-23^{\circ} \mathrm{C}\right)$ by the whole-cell patch-clamp technique (Baglioni et al., 2009; Margheri et al., 2012); both voltage-clamp and current-clamp modes were used. 


\subsubsection{Solutions}

Experiments performed to evaluate the membrane passive properties (membrane conductance, $G_{\mathrm{m}}$, and cell capacitance, $C_{\mathrm{m}}$ ) and resting membrane potential were carried out in Normal Tyrode bath solution with the following composition (mM): $\mathrm{NaCl}$ 140, $\mathrm{KCl} 5.4, \mathrm{CaCl}_{2} 1.5, \mathrm{MgCl}_{2}$ 1.2, glucose 5.5, and HEPES/NaOH 5 (pH 7.35). For $\mathrm{K}^{+}$and $\mathrm{Ca}^{2+}$ currents records we used a modified Normal Tyrode solution with different specific channels blockers added: TTX $(1 \mu \mathrm{M})$ to block voltage activated $\mathrm{Na}^{+}$channels, 4-aminopyridine $(2 \mathrm{mM})$ to block the 4-aminopyridine sensitivetransient outward potassium current $\left(I_{\text {to }}\right)$ and $\mathrm{BaCl}_{2}(0.4 \mathrm{mM})$ to block the inward rectifier $\mathrm{K}^{+}$current, $I_{\text {Kir }}$. To record only $\mathrm{K}^{+}$ currents without any inward $\mathrm{Ca}^{2+}$ current contamination we added nifedipine $(10 \mu \mathrm{M})$ and $\mathrm{Ni}^{2+}(50 \mu \mathrm{M})$ to block L- and T-type $\mathrm{Ca}^{2+}$ current, respectively or $\mathrm{Cd}^{2+}(0.8 \mathrm{mM})$ to block both the types. To evaluate the presence of the voltage- and $\mathrm{Ca}^{2+}$ dependent delayed-rectifier iberiotoxin-sensitive $\mathrm{K}^{+}$current $\left(I_{\mathrm{BK}}\right)$, of the slowly activating chromanol-sensitive $\mathrm{K}^{+}$current $\left(I_{\mathrm{Ks}}\right)$ and of the fast activating $\alpha$-dendrotoxin-sensitive $\mathrm{K}^{+}$current, $I_{\mathrm{K}(\mathrm{V}) \text {, we }}$ performed a pharmacological dissection as previously reported (Baglioni et al., 2012). Briefly, we first applied the stimulation protocol in control condition to record the total $\mathrm{K}^{+}$current traces $\left(I_{\mathrm{K}, \text { tot }}\right)$. This was the result of the amount of all the three $\mathrm{K}^{+}$ currents mentioned above plus a residual current $\left(I_{\mathrm{x}}\right)$, due to other currents that were not eliminated or not completely blocked by our procedure. After that, we generally applied the selective drugs in the following sequence: Chr, IbTx and $\alpha$-DTX to block $I_{\mathrm{Ks}}, I_{\mathrm{BK}}$ and $I_{K(V)}$, respectively. After $\mathrm{Chr}$ application, the remaining currents were $I_{\mathrm{BK}}+I_{\mathrm{K}(\mathrm{V})}+I_{\mathrm{x}}$; after $\mathrm{Chr}$ and $\mathrm{IbTx}$ application, $I_{\mathrm{K}(\mathrm{V})}+I_{\mathrm{x}}$ remained and, finally, after Chr, IbTx and $\alpha$-DTX addition, only $I_{x}$ remained. Subsequently, the current traces obtained in the presence of $\mathrm{Chr}$ were subtracted from those recorded in control condition to obtain the slowly activating $I_{\mathrm{Ks}}$ current; then, the traces recorded in the presence of $\mathrm{Chr}$ and IbTx were subtracted from traces in $\mathrm{Chr}$ to assess the $\mathrm{I}_{\mathrm{BK}}$ current time course. Finally, the traces recorded in the presence of Chr, IbTx and $\alpha$-DTX were subtracted from Chr and IbTx traces to observe the fast activating $I_{\mathrm{K}(\mathrm{V})}$ time course.

Experiments aimed to record only $\mathrm{Ca}^{2+}$ currents were performed in a high-TEA solution $\left(\mathrm{Na}^{+}\right.$- and $\mathrm{K}^{+}$-free $)(\mathrm{mM})$ : $\mathrm{CaCl}_{2} 10$, TEABr 145 and HEPES 10.

Patch pipettes had tip resistances of 3-7 M $\Omega$. For $\mathrm{K}^{+}$currents records, they were filled with a solution containing $(\mathrm{mM}): \mathrm{KCl} 130$, $\mathrm{NaH}_{2} \mathrm{PO}_{4} 10, \mathrm{CaCl}_{2}$ 0.2, EGTA 1, MgATP 5 and HEPES 10. pH was set to 7.2 with $\mathrm{KOH}$. For $\mathrm{Ca}^{2+}$ currents records, the same kind of electrodes were filled with (mM): $150 \mathrm{CsBr}, 5 \mathrm{MgCl}_{2}, 10$ EGTA and 10 HEPES. pH was set to 7.2 with $\mathrm{CsOH}$.

\subsubsection{Stimulation protocols}

The $\mathrm{Ca}^{2+}$ currents activation pulse protocol consisted of 1-s long step pulses applied to cells held at $-80 \mathrm{mV}$ and ranging from -70 to $50 \mathrm{mV}$ in $10 \mathrm{mV}$ increments. The protocol used an interval of $20 \mathrm{~s}$ between stimulating episodes for recovery. The steadystate inactivation was studied by a two-pulse protocol with 1-s pre-pulses to different voltages followed, after $500 \mathrm{~ms}$, by 1 -s test pulse fixed to -20 or $0 \mathrm{mV}$ for $\mathrm{T}$ - and L-type $\mathrm{Ca}^{2+}$ currents, respectively. Again, in the two-pulse protocol, we used an interval of $10 \mathrm{~s}$ between stimulating episodes for recovery. All the activation and inactivation protocols were repeated twice. The steadystate ionic current activation was evaluated by: $I_{\mathrm{a}}(V)=G_{\max }$ $\left(V-V_{\text {rev }}\right) /\left\{1+\exp \left[\left(V_{\mathrm{a}}-V\right) / k_{\mathrm{a}}\right]\right\}$ and steady-state inactivation by: $I_{\mathrm{h}}(V)=I /\left\{1+\exp \left[-\left(V_{\mathrm{h}}-V\right) / k_{\mathrm{h}}\right]\right\}$, where $G_{\max }$ is the maximal conductance for the $I_{\mathrm{a}} ; V_{\mathrm{rev}}$ is the apparent reversal potential; $V_{\mathrm{a}}$ and $V_{\mathrm{h}}$ are the potentials eliciting the half-maximal activation and inactivation values, respectively; $k_{\mathrm{a}}$ and $k_{\mathrm{h}}$ are the steepness factors. The passive properties parameters were evaluated as previously described (Baglioni et al., 2009). Linear leak and capacitive currents were canceled on-line using the $\mathrm{P} / 4$ procedure. This procedure also minimized the not-voltage dependent currents such as those flowing through intermediate-conductance $\mathrm{Ca}^{2+}$-activated $\mathrm{K}^{+}$channels, IKCa (Haren et al., 2010), and stretch activated channels (Formigli et al., 2007; Sbrana et al., 2008).

The total $\mathrm{K}^{+}$current $\left(I_{\mathrm{K}, \text { tot }}\right)$ flowing through delayed rectifier channels was recorded in modified Normal Tyrode solution, evoked in voltage clamp mode by applying voltage steps in $10 \mathrm{mV}$ increments from a holding potential (HP) of $-80 \mathrm{mV}$. Moreover, to minimize $\mathrm{Ca}^{2+}$ currents that could counterbalance the outward $\mathrm{K}^{+}$currents we used an HP of -60 and $-40 \mathrm{mV}$ or, in some experiments, nifedipine and $\mathrm{Ni}^{2+}$. To analyse the $\mathrm{Ca}^{2+}$ and voltage- dependent $\mathrm{K}^{+}$current, $I_{B K}$, two procedures were used. First, the $I_{B \mathrm{~K}}$ voltage-dependence in the MCF-7 cells was investigated as reported in Margheri et al. (2012). Then, the $\mathrm{Ca}^{2+}$ dependence of $I_{B \mathrm{~K}}$ was studied using a double-pulse protocol according to Prakriya and Lingle (1999) in modified Normal Tyrode solution with $\alpha$-DTX $(10 \mathrm{nM})$ and $\mathrm{Chr}(50 \mu \mathrm{M})$ added to block $I_{\mathrm{K}(\mathrm{V})}$ and $I_{\mathrm{Ks}}$ In brief, the voltage command consisted of a double-pulse protocol with a test potential of $400 \mathrm{~ms}$ to $70 \mathrm{mV}$ preceded by a pre-pulse to $0 \mathrm{mV}$. This test pulse to $70 \mathrm{mV}$ allowed the $I_{B \mathrm{~K}}$ occurrence without $\mathrm{Ca}^{2+}$ influx or with just a reduced one, since this voltage value is close to the $\mathrm{Ca}^{2+}$ reversal potential. The prepulse to $0 \mathrm{mV}$ was used to activate the maximal inward $\mathrm{Ca}^{2+}$ currents. In order to evaluate the $I_{B K} \mathrm{Ca}^{2+}$-dependence we increased the $\mathrm{Ca}^{2+}$ influx by increasing the pre-pulse duration. This was increased from 5 to $25 \mathrm{~ms}$ in 5 -ms increments and from 25 to $95 \mathrm{~ms}$ in $10-\mathrm{ms}$ increments.

The $C_{\mathrm{m}}$ value was considered as an index of the cell surface area assuming that membrane-specific capacitance is constant at $1 \mu \mathrm{F} / \mathrm{cm}^{2}$. The total current amplitude $\left(I_{\text {tot }}\right)$ of each type of channel investigated was used as an index of the total channel functionality, whereas current values normalized to cell linear capacitance $\left(I / C_{\mathrm{m}}\right)$ was referred to as current density. Current records were considered reliable when the rundown of $C_{\mathrm{m}}$, resting membrane potential or the studied ionic current size was less than $5 \%$.

\subsection{Statistical analysis}

Mathematical and statistical analysis of electrophysiological data was performed by pClamp9 (Axon Instruments) and SigmaPlot (Jandel Scientific). The Kolmogorov-Smirnov test was used to verify normal distribution of the data. ANOVA was applied for multiple comparisons, followed by the Dunnett's post-hoc test. The number of cells used is indicated as $n$ in figures and table legends. Data are expressed as the mean \pm S.E.M. Statistical significance was determined by one-way ANOVA and Newman-Keuls multiple comparison for analysis of cell growth/viability assay or Student's $t$ test. A $P$ value $\leq 0.05$ was considered significant. Calculations were performed using GraphPad Prism software (GraphPad, San Diego, CA, USA).

\section{Results}

\subsection{Melatonin reduces $\mathrm{Ca}^{2+}$ currents in $\mathrm{MCF}-7$ cells}

To estimate the effect of melatonin on ion currents known to have a role in cell proliferation, we firstly focused on T- and L-type $\mathrm{Ca}^{2+}$ currents. Since several studies demonstrated that human mammary cancer cell lines express voltage-dependent $\mathrm{Ca}^{2+}$ channels (Bertolesi et al., 2002; Ohkubo and Yamazaki, 2012), we intended to evaluate the effects of melatonin on voltage-dependent $\mathrm{Ca}^{2+}$ currents in MCF-7 cells cultured in growth medium. In control conditions we 

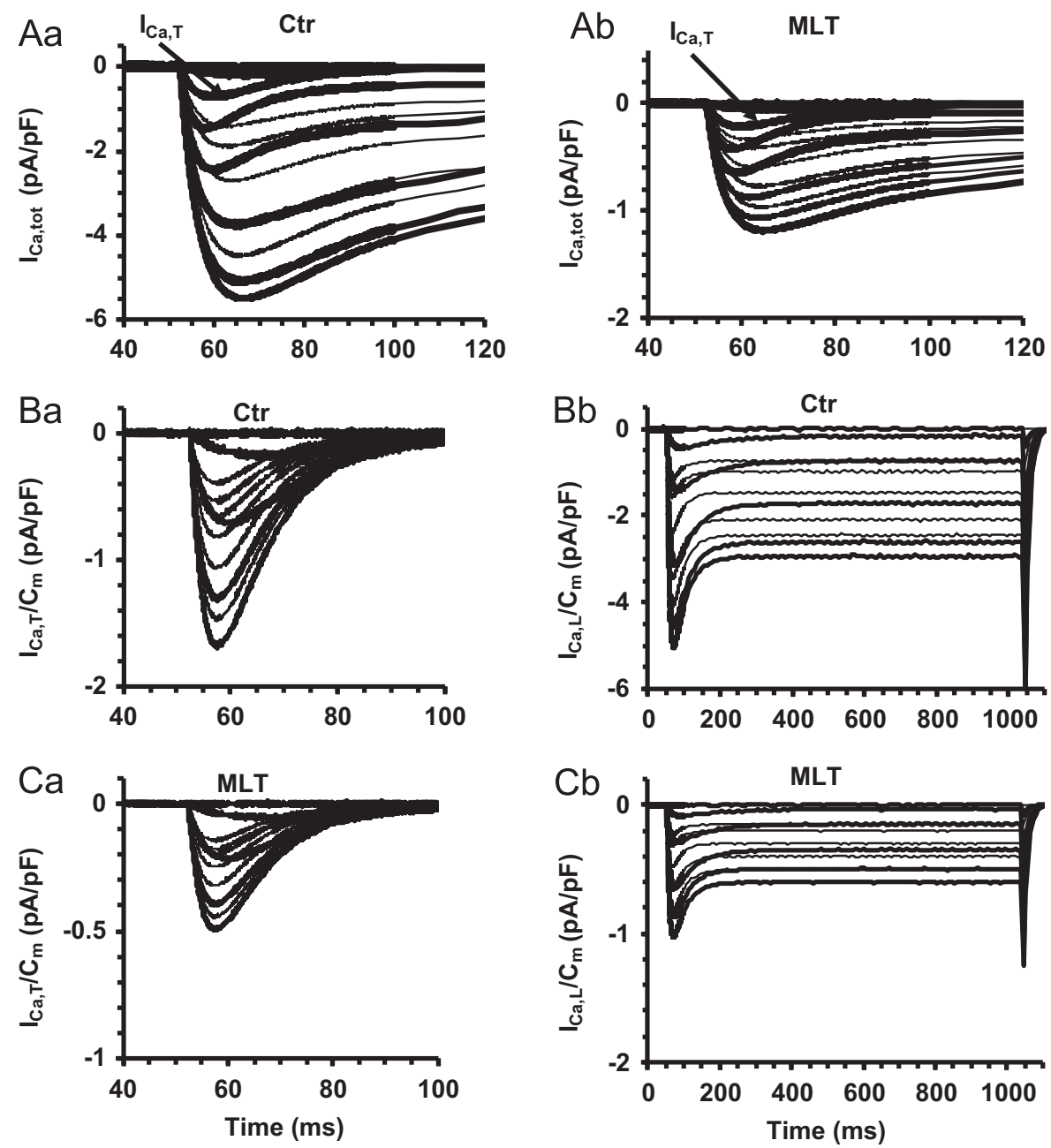

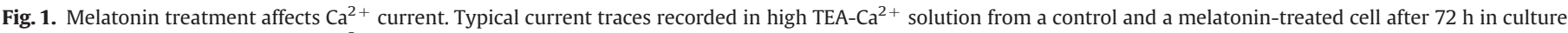

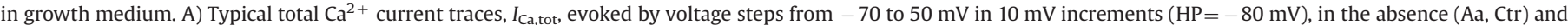

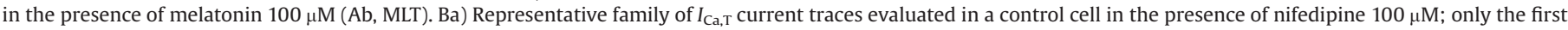

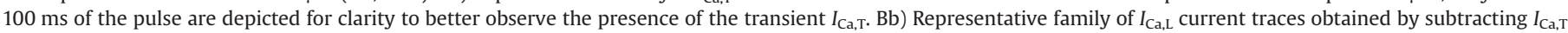
from the $I_{\mathrm{Ca}, \text { tot }}$ traces. C) $I_{\mathrm{Ca}, \mathrm{T}}(\mathrm{a})$ and $I_{\mathrm{Ca}, \mathrm{L}}(\mathrm{b})$ from a melatonin-treated cell. Note the different ordinate scale between panels Ba and Ca, as well as Bb and $\mathrm{Cb}$.

could observe a low voltage-activated inward transient current starting from $-60 \mathrm{mV}$ up to $-40 \mathrm{mV}$. For further depolarizing voltage steps a slowly activating and decaying current superimposed on such a transient current (Fig. 1Aa). When nifedipine was added to the bath solution, only the transient response was recorded (Fig. 1Ba). This latter was no longer detectable when $\mathrm{Ni}^{2+}$ was added in the recording chamber (not shown), so we assumed it was $I_{\mathrm{Ca}, \mathrm{T}}$. Since no $\mathrm{Ca}^{2+}$ currents were observed in the presence of $\mathrm{Ni}^{2+}$ and nifedipine, we reasonably suppose that the only type of high voltage activated $\mathrm{Ca}^{2+}$ channel expressed on MCF-7 cells was the L-type one. Thus, the related L-type $\mathrm{Ca}^{2+}$ current was obtained by subtracting $I_{\mathrm{Ca}, \mathrm{T}}$ from the total $I_{\mathrm{Ca}}$ current (Fig. $1 \mathrm{Bb}$ ). The resulting L-type $\mathrm{Ca}^{2+}$ current, $I_{\mathrm{Ca}, \mathrm{L}}$, generated by a $0 \mathrm{mV}$ pulse peaked at about $20 \mathrm{~ms}$ and after an early fast inactivation with a time constant of about $20 \mathrm{~ms}$, it was followed by a slowly decaying phase after about $200-250 \mathrm{~ms}$ having a time constant of about $280 \mathrm{~ms}$.

Melatonin treatment was able to clearly reduce $I_{C a, t o t}$ size (Fig. 1Ab). In particular, we observed the decrease in amplitude of both $\mathrm{Ca}^{2+}$ current types (Fig. $1 \mathrm{Ca}$ and $\mathrm{Cb}$ ) as compared to control cells. Moreover, the voltage eliciting the maximal peak current size was positively shifted of about 5 and $10 \mathrm{mV}$ for $I_{\mathrm{Ca}, \mathrm{T}}$ and $I_{\mathrm{Ca}, \mathrm{L}}$, respectively (Table 1 ). Therefore, melatonin was able to shift the voltage dependence of $I_{\mathrm{Ca}, \mathrm{T}}$ and $I_{\mathrm{Ca}, \mathrm{L}}$ towards positive potentials.
Then, the mean peak current value estimated in all the experiments done was plotted vs. voltage (Fig. 2A). The analysis of the Boltzmann curves fitted to the normalized $I-V$ data for activation and inactivation of both $\mathrm{Ca}^{2+}$ currents types (Fig. 2B and $\mathrm{C}$ ), shows that melatonin positively shifted the $V_{\mathrm{a}}$ values for $I_{\mathrm{Ca}, \mathrm{T}}$ and $I_{\mathrm{Ca}, \mathrm{L}}$ activation of about 5 and $10 \mathrm{mV}$, respectively (Table 1). In contrast, we did not observe any significant shift of $V_{\mathrm{h}}$ neither for $I_{\mathrm{Ca}, \mathrm{T}}$ or $I_{\mathrm{Ca}, \mathrm{L}}$.

$I_{\mathrm{Ca}, \mathrm{L}}$ steady-state inactivation showed an U-shaped curve. Notably, the decaying branch at negative potentials was not affected by melatonin, but that at positive potentials was reduced (Fig. 2C).

Interestingly, by analysing the best fit to the resulting $I-V$ curves we could clearly observe that the reversal potential was positively shifted in both the current types in a similar amount of about $8 \mathrm{mV}$ (Fig. 2Aa and $\mathrm{Ab}$, showed in detail in 2Ac; compare red triangles and blue circles related to melatonin vs. black symbols, related to $\mathrm{Ctr}$ ). From the estimated value of the $I_{\mathrm{Ca}}$ reversal potential resulting in melatonin-treatment, we could suggest that melatonin may be able to induce a decrease of free $\left[\mathrm{Ca}^{2+}\right]_{\mathrm{i}}$. This assumption was confirmed by experiments of $\mathrm{Ca}^{2+}$ imaging showing that in melatonin-treated cells the resting $\left[\mathrm{Ca}^{2+}\right]_{i}$ was actually reduced by about $50 \%$ with respect to control cells (Fig. 3). 


\subsection{Melatonin treatment affects different types of $\mathrm{K}^{+}$currents in MCF-7 cells}

To test melatonin effects on $\mathrm{K}^{+}$currents in MCF-7 cells, we performed a detailed electrophysiological analysis. First, the

\section{Table 1}

MLT affects Boltzmann parameters of $I_{\mathrm{Ca}}$ and $I_{\mathrm{Ca}}$ activation and inactivation. MLT decreases the maximum peak size of $I_{\mathrm{Ca}, \mathrm{T}}$ and $I_{\mathrm{Ca}, \mathrm{L}}$, indexes of the inhibitory effect on these channels activity; moreover it shifts the voltage threshold and the voltage values eliciting the maximal peak current in the $I-V$ plots $\left(V_{\mathrm{p}}\right)$ and the $V_{\mathrm{a}}$ Boltzmann parameters of activation for both $I_{\mathrm{Ca}, \mathrm{T}}$ and $I_{\mathrm{Ca}, \mathrm{L}}$ towards more positive potentials. MLT did not affect the parameters $k_{\mathrm{a}}, k_{\mathrm{h}}$ and $V_{\mathrm{h}}$ for both $I_{\mathrm{Ca}, \mathrm{T}}$ and $I_{\mathrm{Ca}, \mathrm{L}}$.

\begin{tabular}{lrr}
\hline Parameters & \multicolumn{1}{c}{ Control } & \multicolumn{1}{c}{ Melatonin } \\
\hline$I_{\mathrm{Ca}, \mathrm{T}}$ & & \\
$I_{\mathrm{Ca}, \mathrm{T}} / C_{\mathrm{m}}(\mathrm{pA} / \mathrm{pF})$ & $1.7 \pm 0.18$ & $0.5 \pm 0.12^{\mathrm{a}}$ \\
$G_{\mathrm{m}} / C_{\mathrm{m}}(\mathrm{pS} / \mathrm{pF})$ & $21.8 \pm 2.00$ & $6.2 \pm 1.30^{\mathrm{a}}$ \\
$V_{\mathrm{p}}(\mathrm{mV})$ & $-30.1 \pm 2.42$ & $-25.2 \pm 1.58^{\mathrm{b}}$ \\
$V_{\mathrm{a}}(\mathrm{mV})$ & $-40.1 \pm 2.68$ & $-35.0 \pm 1.71^{\mathrm{c}}$ \\
$k_{\mathrm{a}}(\mathrm{mV})$ & $5.5 \pm 0.43$ & $5.5 \pm 0.52$ \\
$V_{\mathrm{rev}}(\mathrm{mV})$ & $58.0 \pm 2.75$ & $61.8 \pm 2.78^{\mathrm{c}}$ \\
$V_{\mathrm{h}}(\mathrm{mV})$ & $-64.6 \pm 4.06$ & $-64.9 \pm 3.10$ \\
$k_{\mathrm{h}}(\mathrm{mV})$ & $4.5 \pm 0.53$ & $4.4 \pm 0.42$ \\
$I_{\mathrm{Ca}, \mathrm{L}}$ & & \\
\hline$I_{\mathrm{Ca}, \mathrm{L}} / C_{\mathrm{m}}(\mathrm{pA} / \mathrm{pF})$ & $4.9 \pm 0.38$ & $2.0 \pm 0.42^{\mathrm{a}}$ \\
$G_{\mathrm{m}} / C_{\mathrm{m}}(\mathrm{pS} / \mathrm{pF})$ & $88.0 \pm 14.21$ & $36.4 \pm 10.24^{\mathrm{a}}$ \\
$V_{\mathrm{p}}(\mathrm{mV})$ & $0.24 \pm 2.05$ & $10.4 \pm 3.08^{\mathrm{a}}$ \\
$V_{\mathrm{a}}(\mathrm{mV})$ & $10.0 \pm 2.09$ & $-5.2 \pm 1.06^{\mathrm{a}}$ \\
$k_{\mathrm{a}}(\mathrm{mV})$ & $7.2 \pm 0.36$ & $7.3 \pm 0.47$ \\
$V_{\mathrm{rev}}(\mathrm{mV})$ & $59.0 \pm 2.76$ & $68.2 \pm 2.73^{\mathrm{c}}$ \\
$V_{\mathrm{h}}(\mathrm{mV})$ & $-55 \pm 3.00$ & $-52.5 \pm 3.02$ \\
$k_{\mathrm{h}}(\mathrm{mV})$ & $7.5 \pm 0.46$ & $7.4 \pm 0.51$ \\
\hline
\end{tabular}

Data are mean \pm S.E.M. and in each experimental condition were from $n=36 / 39$ cells.

a $P<0.005$ respect to control (Student's $t$-test).

${ }^{\mathrm{b}} P<0.01$.

${ }^{\mathrm{c}} \mathrm{P}<0.05$. different types of $\mathrm{K}^{+}$currents recorded were identified by a pharmacological dissection. After that, we performed the same experiments on melatonin-treated cells. A representative experiment related to cells cultured for $72 \mathrm{~h}$ in growth medium is reported in Fig. 4: it shows an example of pharmacological dissection of $\mathrm{K}^{+}$currents in a typical MCF-7 cell where only the current response to a $50-\mathrm{mV}$ pulse is displayed, either in an untreated (Ctr) or in a melatonin-treated cell (MLT).

Representative currents elicited at any step potential are depicted as current density in Fig. 5 and referred to $I_{\mathrm{K}, \text { tot }}(\mathrm{A}), I_{\mathrm{BK}}$ (B), $I_{\mathrm{Ks}}(\mathrm{C})$ and $I_{\mathrm{K}(\mathrm{V})}$ (D) from untreated (panels a, Ctr) and melatonin-treated cells (panels b, MLT). It can be clearly seen that melatonin treatment caused a reduction in $I_{\mathrm{K}, \text { tot }}$ density (Fig. $5 \mathrm{Aa}$ and $\mathrm{Ab}$ ). Thanks to the pharmacological dissection (see Section 2), we could assess that such a decrease was mostly due to the strong decline of $I_{\mathrm{BK}}$ and $I_{\mathrm{K}(\mathrm{V})}$ current density (about 0.3 and 0.4 fold, respectively, Fig. 5B and D). In contrast, melatonin treatment appeared to increase $I_{\mathrm{Ks}}$ current density (about 1.6 fold, Fig. 5C). The $I-V$ plots related to all the experimental data confirmed this conclusion (panels c).

\subsection{Effect of melatonin treatment on $\mathrm{I}_{B K} \mathrm{Ca}^{2+}$-dependence}

Due to the striking role likely played by $I_{\mathrm{BK}}$ in MCF-7 cells cultured in growth medium, we aimed to study in detail its $\mathrm{Ca}^{2+}$-dependence. Thus, to evaluate the entity of melatonin effects on $I_{\mathrm{BK}} \mathrm{Ca}^{2+}$. dependence we applied the two-pulse protocol in MCF-7 cells (see Methods). $I_{\mathrm{Ca}}$ recorded by stepping the voltage to $0 \mathrm{mV}$ in the absence and presence of $\mathrm{Cd}^{2+}(0.8 \mathrm{mM})$ is shown in Fig. 6A. In the absence of $\mathrm{Cd}^{2+}$ we recorded an inward current $\left(I_{\mathrm{Ca}}\right)$ followed by an outward one ( $I_{\mathrm{BK}}$, blue traces), that was completely blocked by $\mathrm{Cd}^{2+}$ (red traces). The effect of $\mathrm{Ca}^{2+}$ influx on $I_{\mathrm{BK}}$ was studied by prepulsing the membrane potential to $0 \mathrm{mV}$ (Fig. 6). When the membrane potential was stepped from $0 \mathrm{mV}$ to $70 \mathrm{mV}$ the current traces showed an instantaneous current $\left(I_{\text {ist }}\right)$ (Marcantoni et al., 2010;
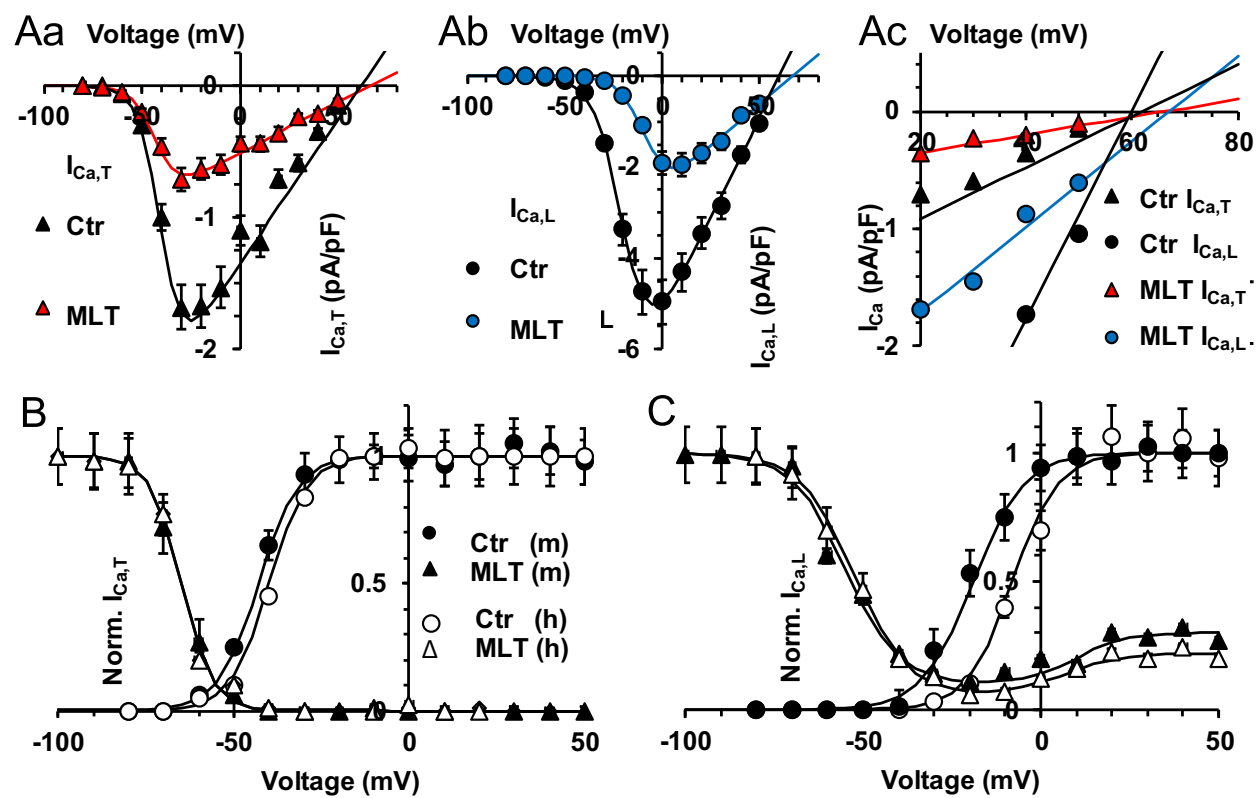

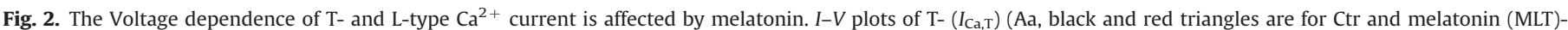

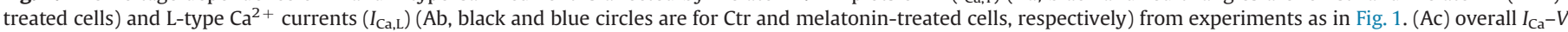

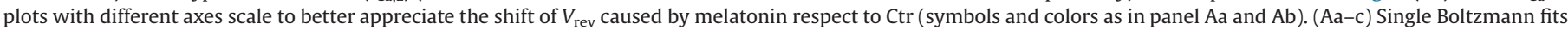

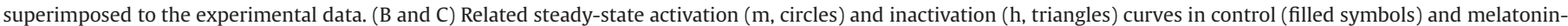

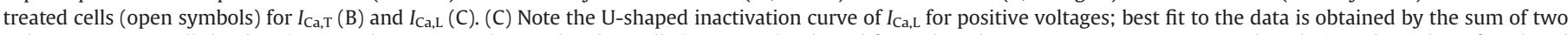

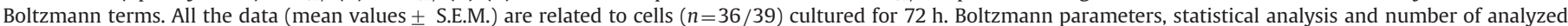
cells are reported in Table 1. (For interpretation of the references to color in this figure legend, the reader is referred to the web version of this article.) 

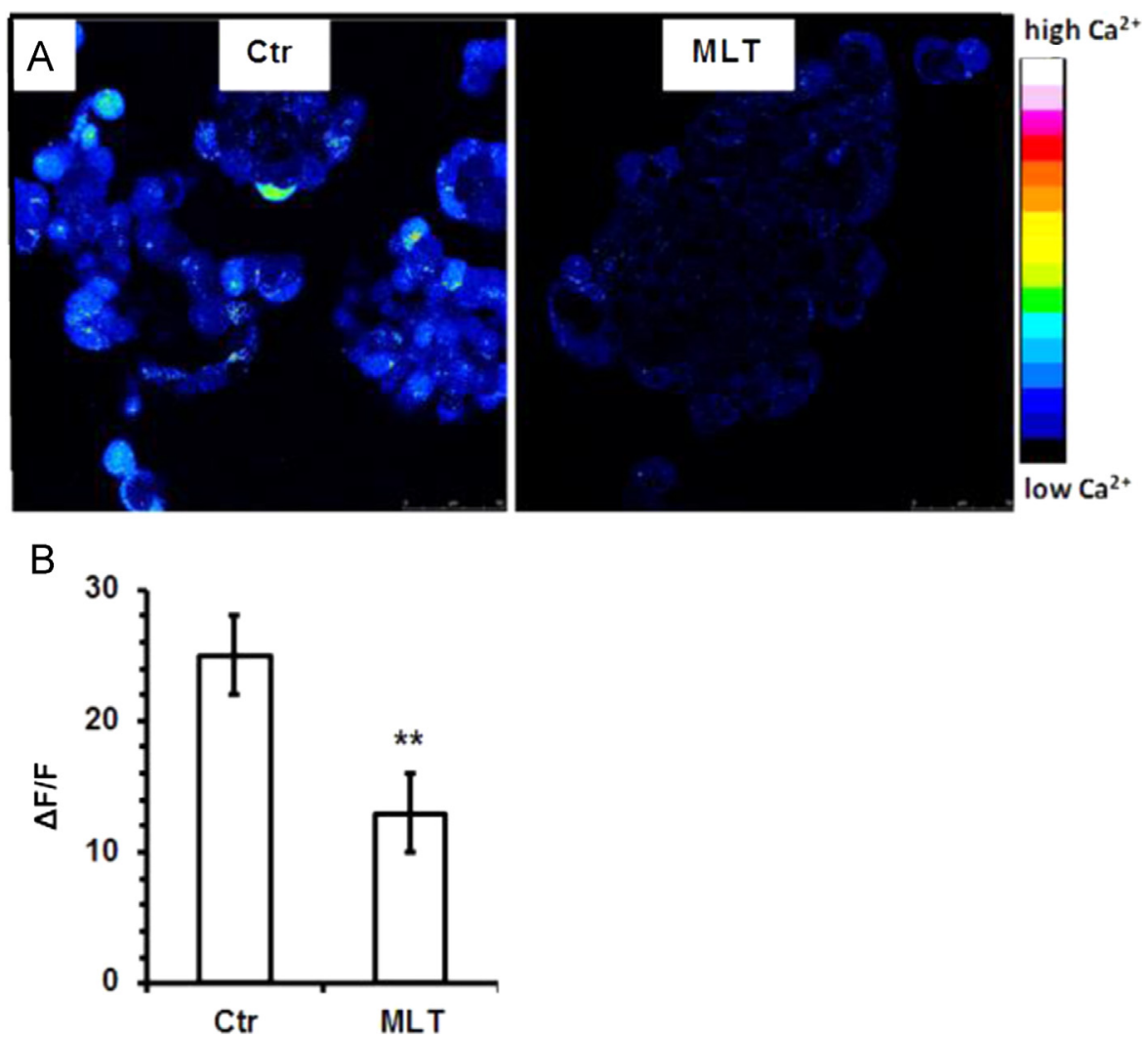

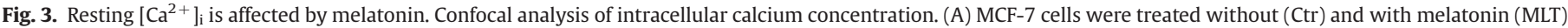

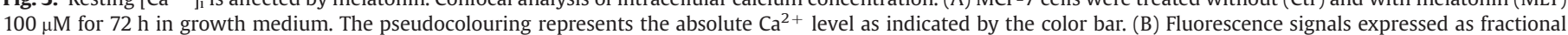

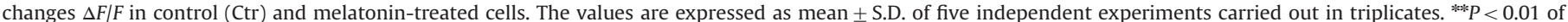
MLT vs. Ctr.
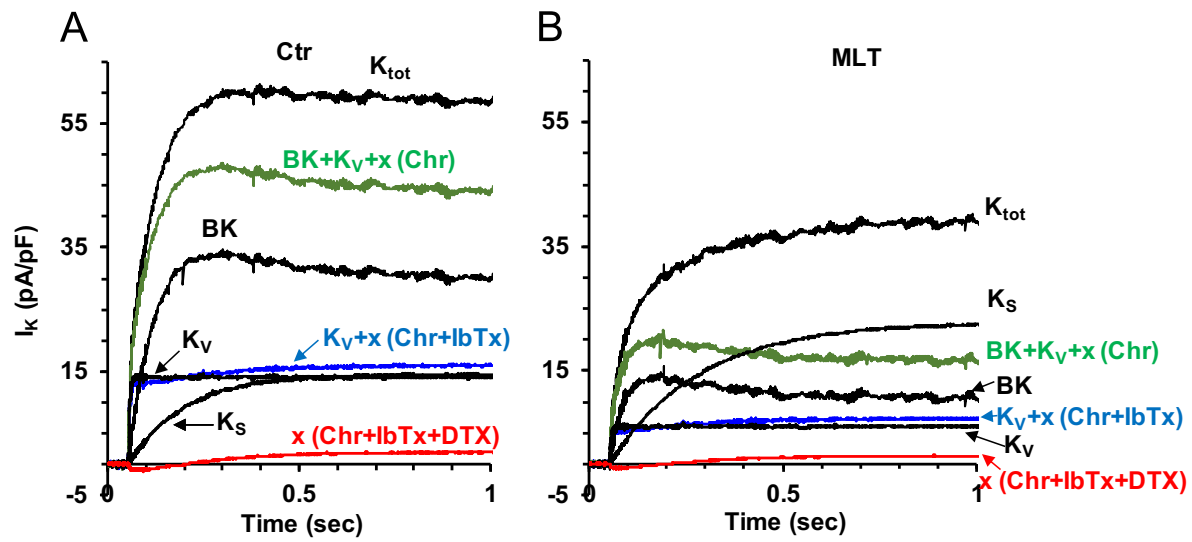

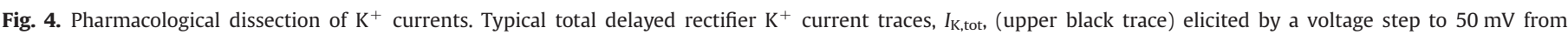

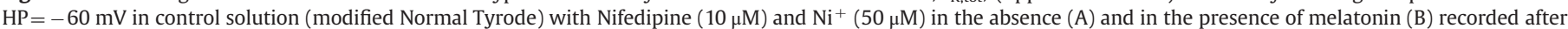

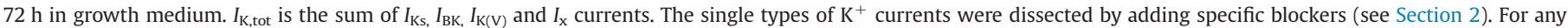

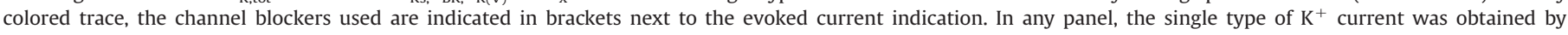

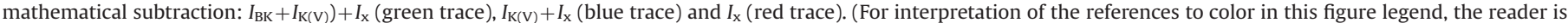
referred to the web version of this article.)

Prakriya and Lingle 1999) followed by a slow increase in the current size. The changes induced by conditioning steps on $I_{\mathrm{p}}$ and $t_{\mathrm{p}}$ were very small and not statistically significant respect to 5-10 ms control test pulse (without pre-pulse). However, as long as the pre-pulse duration increased, $I_{\mathrm{p}}$ progressively augmented (Fig. 6a), $t_{\mathrm{p}}$, evaluated from the beginning of the $70-\mathrm{mV}$ pulse, decreased (Fig. 6c) and the time constant of the decay became faster, changing from $210 \pm 0.28 \mathrm{~ms}$ (without pre-pulse) to $112 \pm 15 \mathrm{~ms}$ (with 75 -ms prepulse). The $I_{\mathrm{p}}$ reached the maximal amplitude and the minimum $t_{\mathrm{p}}$ for $75-\mathrm{ms}$ pre-pulse (Fig. 6a and c). The $I_{\mathrm{BK}}$ maximal size ( $I_{\mathrm{p}}$ value) elicited by a 75 -ms pre-pulse increased $1.7 \pm 0.2$ fold $(n=7)$ with respect to that evoked without the pre-pulse.

$I_{\mathrm{BK}}$ was then recorded in melatonin-treated cells cultured in growth medium for $72 \mathrm{~h}$, by the two-pulse protocol and the same recording solutions used in untreated cells. The effects on $t_{\mathrm{p}}$ and time constant of the decay time-dependence were not statistically different from those observed in control (Fig. 6c) but the increase of $I_{\mathrm{p}}$ amplitude was smaller as long as the pre-pulse duration increased, reaching a quasi-steady state over 45 -ms duration. In such an interval the increment was only $1.4 \pm 0.2(n=7)$. The 

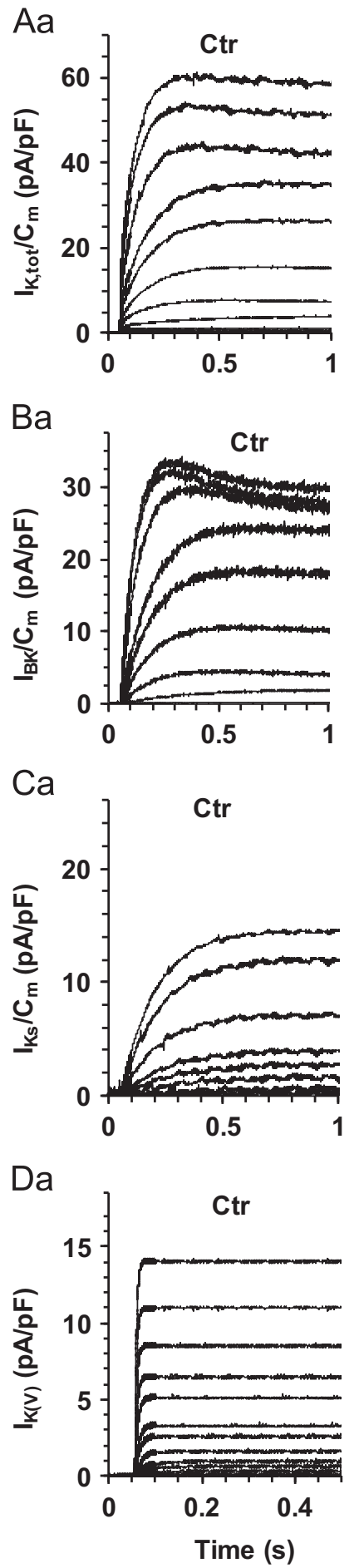

b

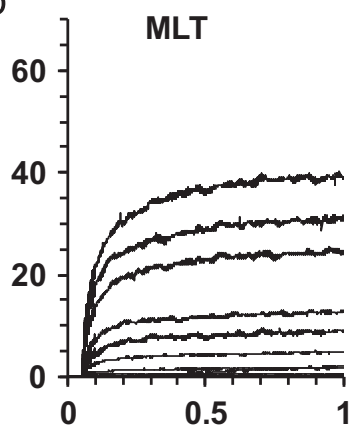

b

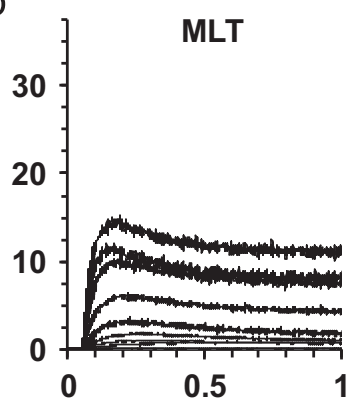

b

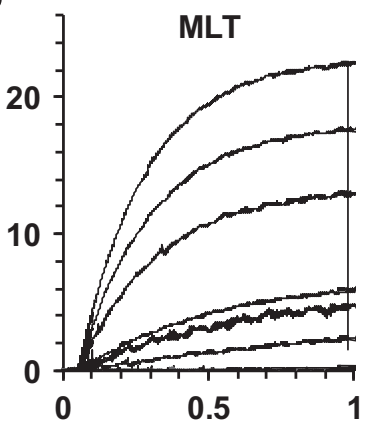

b

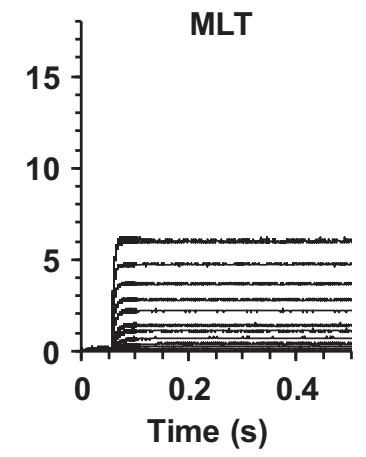

C

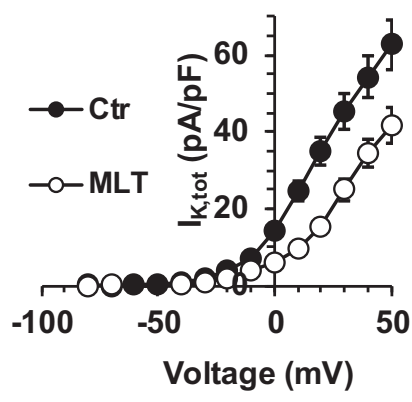

C

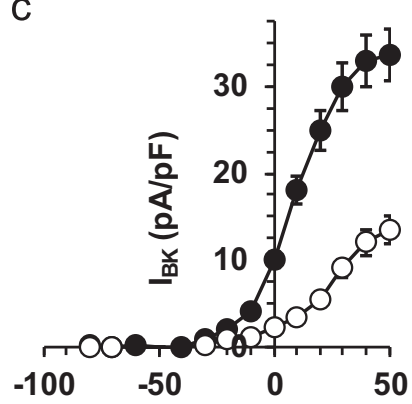

C

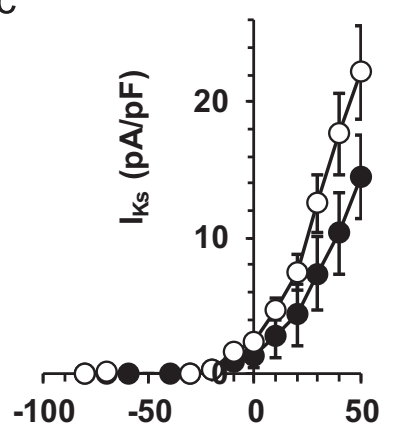

C

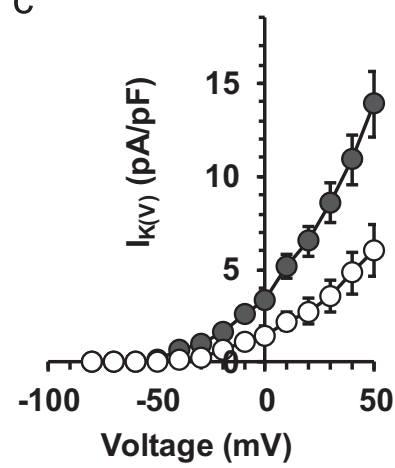

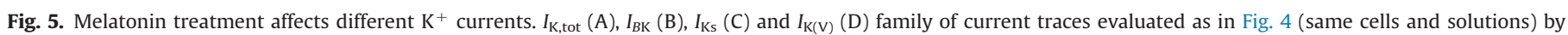

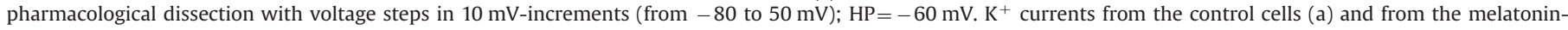

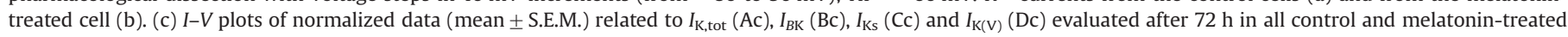
cells. Number of analyzed cells: Ctr $n=44$; melatonin $n=40$.

enhancement of $I_{\text {ist }}$ occurred after $25 \mathrm{~ms}$ in control condition and after $45 \mathrm{~ms}$ under melatonin treatment. The $I_{\text {ist }}$ enhancement in control was similar to $I_{\mathrm{p}}(1.6 \pm 0.2)$ whereas it was reduced in melatonin-treated cells to $1.2 \pm 0.1(P<0.05)$.

Finally, to test the role of $I_{\mathrm{Ca}, \mathrm{T}}$ on $I_{\mathrm{BK}} \mathrm{Ca}^{2+}$ dependence we blocked $I_{\mathrm{Ca}, \mathrm{L}}$ with nifedipine. Since no difference was found between $I_{\mathrm{BK}}$ evaluated with and without pre-pulse (not shown), we suggest that T-type $\mathrm{Ca}^{2+}$ channels have a marginal role, if any, in modulating $I_{\mathrm{BK}}$ channels, possibly depending on the small amount of $\mathrm{Ca}^{2+}$ entry due to its fast transient time course and small size, or because of their location too far from BK channels.

\subsection{Melatonin affects MCF-7 cells proliferation and growth/viability}

To confirm the previous finding on the effect of melatonin on proliferation on MCF-7 cells cultured in growth medium in the absence (control) or presence of melatonin for $72 \mathrm{~h}$ the nuclear levels of Ki-67, a well-known marker of cell cycle and proliferation 

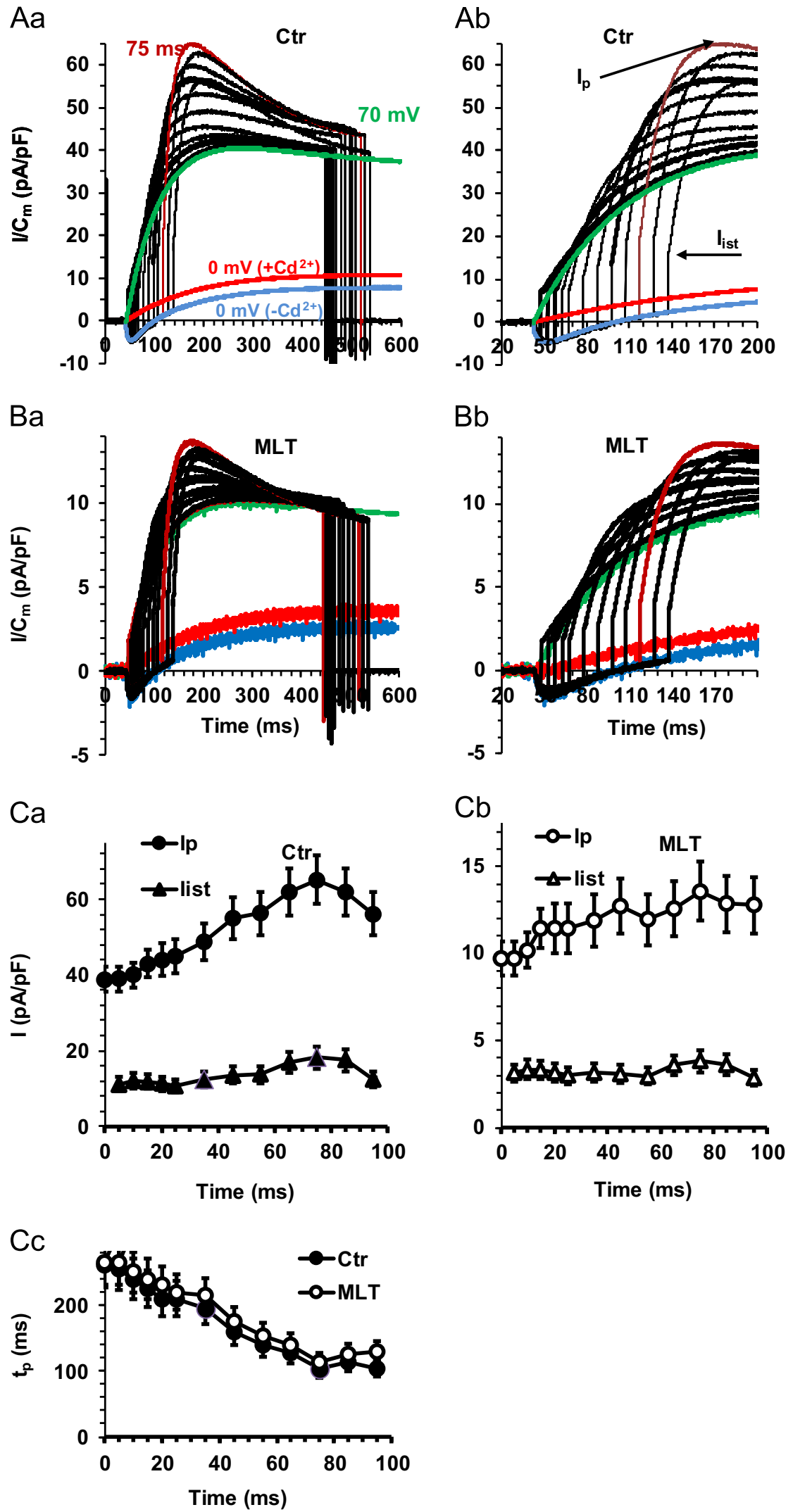

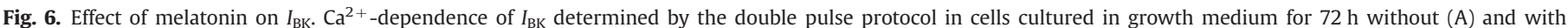

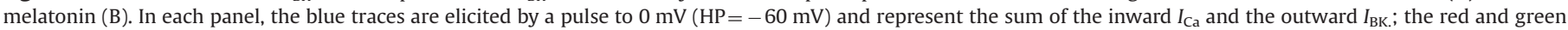

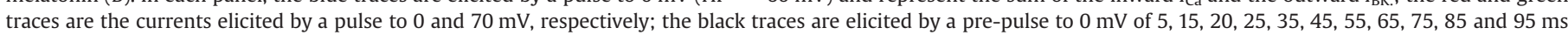

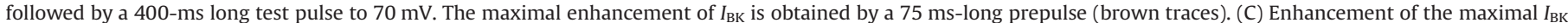

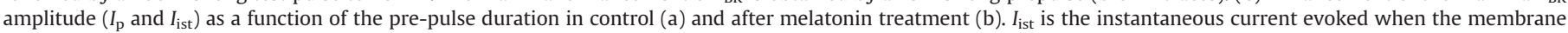

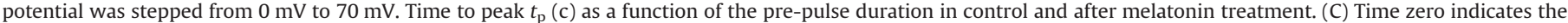
values recorded without the pre-pulse. (For interpretation of the references to color in this figure legend, the reader is referred to the web version of this article.) 

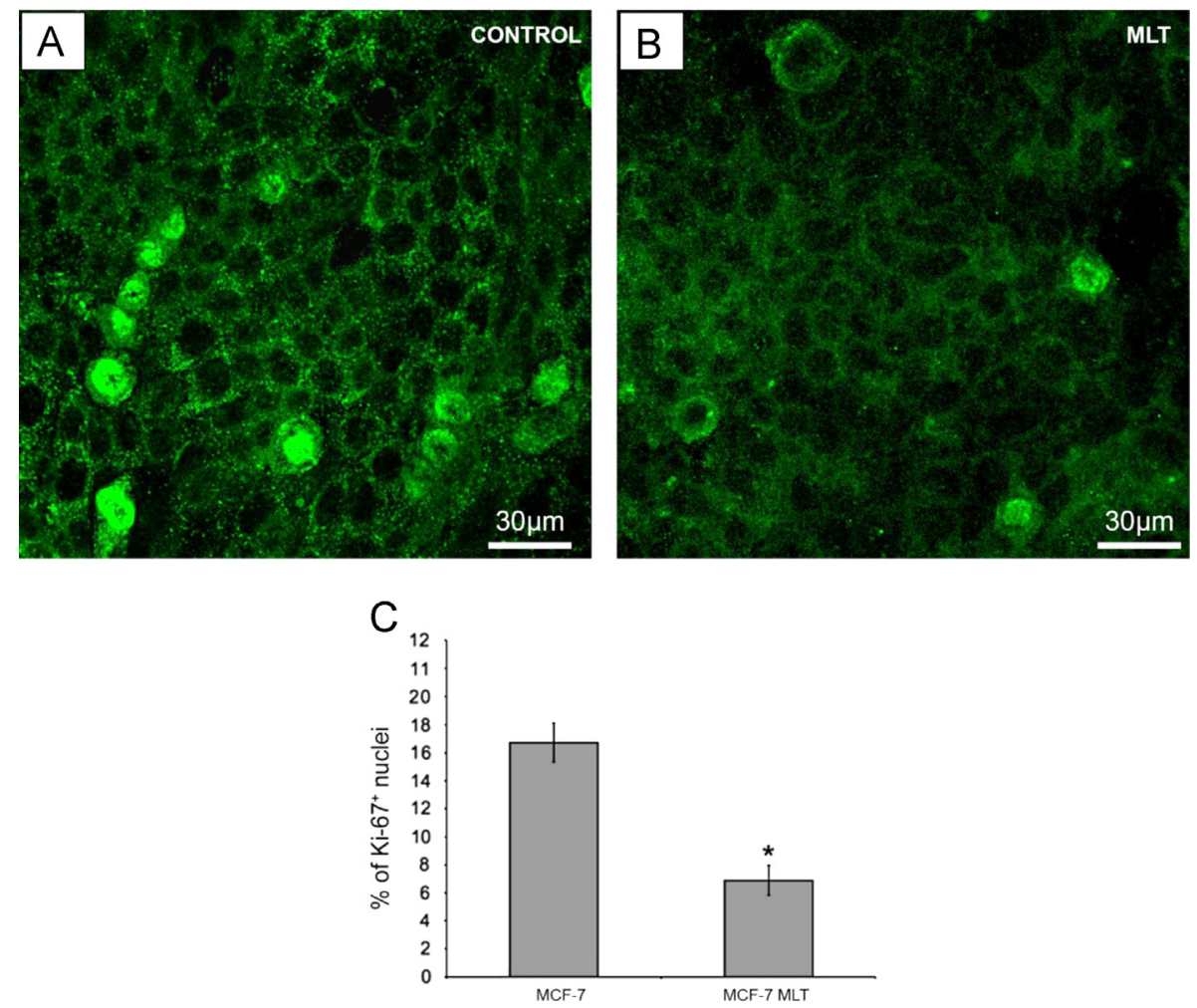

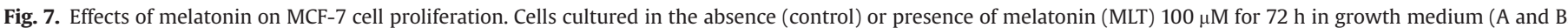

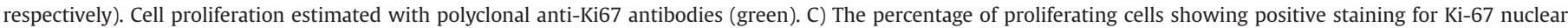

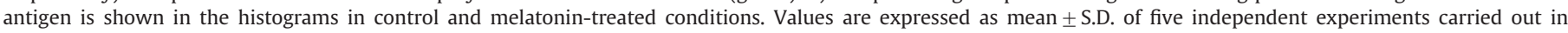
triplicates. ${ }^{*} P<0.05$ MLT vs. Ctr. (For interpretation of the references to color in this figure legend, the reader is referred to the web version of this article.)

were evaluated. Once more it was confirmed that the proliferating cells under melatonin treatment were reduced to about $40 \%$ with respect to the untreated ones (Fig. 7A-C). To assess MCF-7 cell growth/viability in growth medium, MTS assay revealed that melatonin was able to induce a statistically significant decline of growth/viability with respect to untreated cells (Fig. 8). The selective ion channel block (Fig. 8) by Nifedipine, $\mathrm{NiCl}_{2}, \alpha$-DTX, IbTx, or Chr caused a slight but statistically significant inhibition of the cell growth/viability investigated by MTS assay with respect to control cells, indicating a significant role of the specific ion currents $I_{\mathrm{Ca}, \mathrm{L}}, I_{\mathrm{Ca}, \mathrm{T}}, I_{\mathrm{K}(\mathrm{V})}, I_{\mathrm{BK}}$ and $I_{\mathrm{Ks}}$ in cell proliferation. The concomitant administration of melatonin with Nifedipine, $\mathrm{NiCl}_{2}$ or IbTx did not induce significant changes with respect to control cells. These results seem to suggest that melatonin is unable to induce a growth/viability decrease through a pathway involving $I_{\mathrm{Ca}, \mathrm{L}} I_{\mathrm{Ca}, \mathrm{T}}$ and $I_{\mathrm{BK}}$. Nevertheless, melatonin further decreased cell growth/viability in the cells pre-treated with $\alpha$-DTX or with Chr, indicating that, even if $I_{\mathrm{K}(\mathrm{V})}$ or $I_{\mathrm{Ks}}$ are blocked, it can still exert its effect of reducing cell growth/viability. Therefore, it seems that the further reduction observed with melatonin in the presence of $\alpha$-DTX or Chr may not strictly depend only on $\mathrm{K}_{(\mathrm{v})}$ or $\mathrm{K}_{\mathrm{s}}$ channels.

\subsection{Effects of melatonin on $C_{m}$, resting membrane potential} and ionic currents

The effects of melatonin in proliferating MCF-7 cells cultured in growth medium were estimated also at different culture times. Records in normal Tyrode solution on control MCF-7 cells cultured for 24,48 and $72 \mathrm{~h}$ in growth medium showed a progressive increase in $C_{\mathrm{m}}$, suggesting that cells underwent an increase in cell surface area; in contrast, in melatonin-treated cells $C_{\mathrm{m}}$ was scarcely affected since at $72 \mathrm{~h}$ it showed a slight and not significant decreased value as compared to the one observed at $24 \mathrm{~h}$ (Fig. 9A).
By using the current-clamp mode we also recorded the resting membrane potential of MCF-7 cells in normal Tyrode solution (Fig. 9B). It was observed that resting membrane potential tended to depolarize with time in untreated cells, whereas in melatonintreated ones, it resulted always significantly hyperpolarized with respect to control, although this effect was stronger at 24 and $48 \mathrm{~h}$, as compared to $72 \mathrm{~h}$.

In control cells, the time-dependent increase of $C_{\mathrm{m}}$ was paralleled by the enhancement of the maximal values of current density and total current amplitudes of $I_{\mathrm{BK}}, I_{\mathrm{Ks}}$ and $I_{\mathrm{K}(\mathrm{V})}$ (Fig. 9C-E) and of $\mathrm{Ca}^{2+}$ currents $\left(I_{\mathrm{Ca}, \mathrm{T}}\right.$ and $\left.I_{\mathrm{Ca}, \mathrm{L}}\right)$ (Fig. $9 \mathrm{~F}$ and $\mathrm{G}$ ). The effects of melatonin treatment on the various types of ion currents according to the culture time were similar. In fact, the time dependent enhancement was generally reduced and the total current values were decreased with respect to those observed in control. A similar trend was observed for $\mathrm{Ca}^{2+}$ current density. Except for $\mathrm{K}_{\mathrm{s}}$, melatonin did not affect the current density and total current amplitudes recorded at $24 \mathrm{~h}$, showing the same mean size as in control, but it strongly decreased the ionic currents at $48 \mathrm{~h}$ and even more at $72 \mathrm{~h}$ (Fig. 9E G). Differently, $I_{\mathrm{Ks}}$ current density in the presence of melatonin was larger than control and increased with time in culture (Fig. 9Da). Moreover, $\mathrm{K}_{\mathrm{s}}$ was the only component whose total current was increased in time in the presence of melatonin (Fig. 9Db), although its size was lesser than Ctr. This indicates that melatonin effect observed on $I_{\mathrm{Ks}}$ density was essentially related to the decrease of $C_{\mathrm{m}}$.

\subsection{Effects of melatonin on cells cultured in differentiation medium}

To verify whether the effect of melatonin was expressing solely on proliferating cells, parallel experiments in MCF-7 cells cultured in differentiation medium, namely DMEM supplemented with a low serum concentration (FBS 2\%). MTS assay to detect growth/viability 


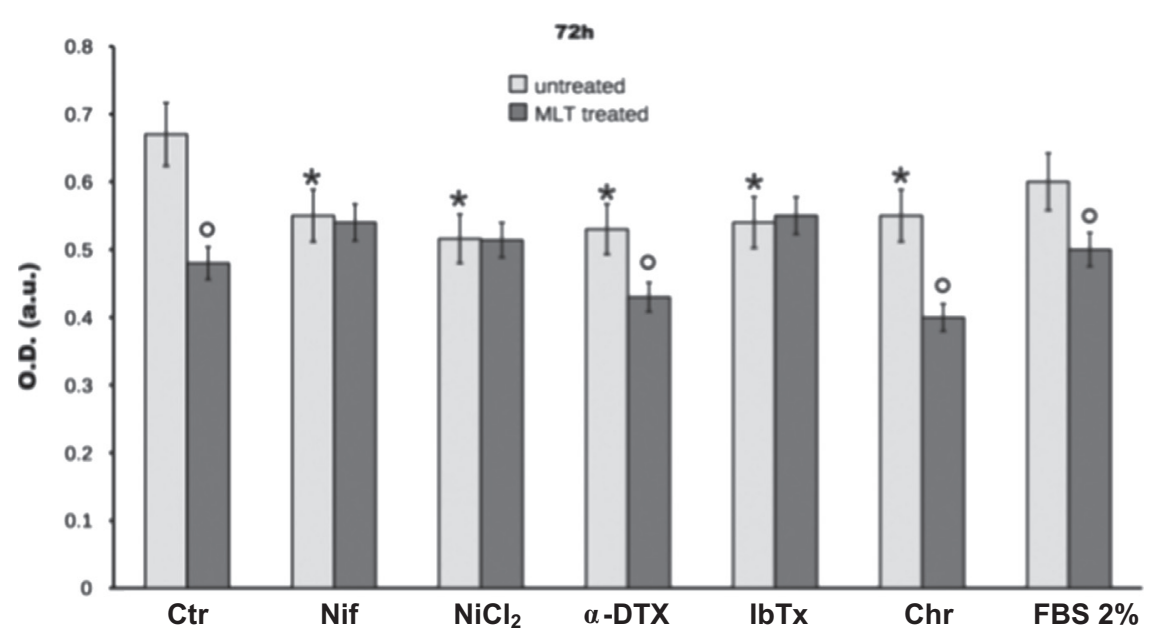

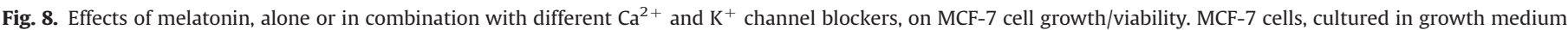

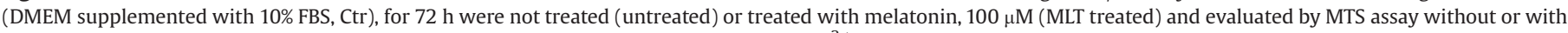

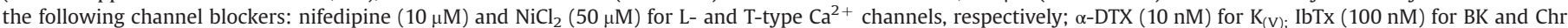

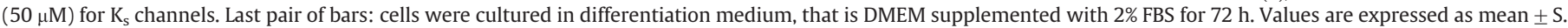

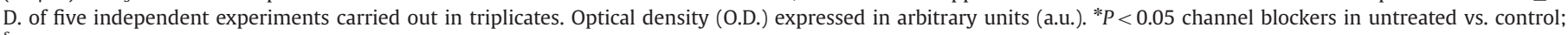
${ }^{\S} \mathrm{P}<0.05$ FBS $2 \%$ vs. Ctr $10 \%$; ${ }^{\circ} \mathrm{P}<0.05$ MLT treated $v$ s. related untreated.

in MCF-7 cells cultured in differentiation medium (Fig. 8) revealed, as expected, a moderate reduction of cell growth/viability compared to the cells maintained in growth medium (indicated as Ctr in Fig. 8). The addition of melatonin significantly reduced growth/viability in differentiating cells, but its effect, in terms of variability reduction was less marked than that exerted on the cells cultured in growth medium (Ctr) suggesting that melatonin as a more marked effect on proliferation rather than on differentiation. After $72 \mathrm{~h}$ in culture, cells grown in differentiation medium $(n=22)$ showed a smaller $C_{\mathrm{m}}$ as compared to control (Fig. 9A, filled diamond), indicating a decrease in surface area with respect to $24 \mathrm{~h}$. The presence of melatonin $(n=20)$ elicited an opposite effect, inducing a $C_{\mathrm{m}}$ increase (open diamond) vs. melatonin treatment in growth medium (open circles). However, this increase in cell surface area did not differ significantly from $C_{\mathrm{m}}$ value estimated in untreated cells after $24 \mathrm{~h}$ in growth medium (filled circle). Moreover, differentiating cells also showed a hyperpolarized resting membrane potential, typical of cells with slow proliferation rate; melatonin caused a further hyperpolarization (Fig. 9B, filled and open diamond, respectively).

The electrophysiological records performed on MCF-7 cells cultured for $72 \mathrm{~h}$ in differentiation medium (filled diamond), showed a reduction of the total current size of all the delayed rectifying outward currents $\left(I_{\mathrm{BK}}, I_{\mathrm{Ks}}, I_{\mathrm{K}(\mathrm{V})}\right)$ with respect to those cultured in growth medium at the same time (Fig. $9 \mathrm{Cb}, \mathrm{Db}$, and $\mathrm{Eb}$, compare filled diamond with filled circles at $72 \mathrm{~h}$ ). Thus, it can reasonably suggested that these currents have a prevalent role in proliferation. This effect was accompanied by a slight reduction of the calculated current density except for $I_{\mathrm{Ks}}$ that, in contrast, showed an increase (Fig. 9Ca, Da, and Ea, filled diamond). Similarly, the current density of $I_{\mathrm{Ca}, \mathrm{T}}$ and $I_{\mathrm{Ca}, \mathrm{L}}$ was strongly augmented (Fig. 9Fa and Ga), whereas the related total currents amplitudes were slightly increased after $72 \mathrm{~h}$ (Fig. 9Fb and $\mathrm{Gb}$ ) with respect to cells grown in growth medium, thus suggesting a role for these channels also in differentiation.

Upon melatonin treatment, the total current values of $I_{\mathrm{BK}}$ and $I_{\mathrm{Ks}}$ recorded from cells in differentiation medium (Fig. $9 \mathrm{Cb}$ and $\mathrm{Db}$, open diamond) were not significantly different respect to those observed at the same time in growth medium (open circles). By contrast, differently to what observed in growth medium, the total current values of $I_{\mathrm{K}(\mathrm{V})}$ (Fig. 9Eb) as well as $I_{\mathrm{Ca}, \mathrm{T}}$ and $I_{\mathrm{Ca}, \mathrm{L}}$ (Fig. 9Fb and $\mathrm{Gb}$ ) were increased. Since the mean total current amplitude of $I_{\mathrm{BK}}$, $I_{\mathrm{Ca}, \mathrm{T}}$ and $I_{\mathrm{Ca}, \mathrm{L}}$ in the presence of melatonin in $2 \%$ FCS medium was definitely lower than that detected in untreated cells (compare open and filled diamonds in Fig. $9 \mathrm{Cb}, \mathrm{Fb}$ and $\mathrm{Gb}$ ). Since $I_{\mathrm{Ks}}$ and $I_{\mathrm{K}(\mathrm{V})}$ showed similar values in the presence or absence of melatonin in differentiation medium (compare open and filled diamonds in Fig. 9Db and $\mathrm{Eb}$ ) it appears reasonable that melatonin has not detectable effects on these channels in the course of differentiation, but only upon proliferation. A similar effect was observed also on $I_{\mathrm{K}(\mathrm{V})}$ current density where only a slight reduction could be seen (Fig. 9Ea), whereas $I_{\mathrm{Ks}}$ current density was sharply decreased (Fig. 9Da). AS for the current density of all other ion currents $I_{\mathrm{BK}}$, $I_{\mathrm{Ks}}, I_{\mathrm{Ca}, \mathrm{T}}$ and $I_{\mathrm{Ca}, \mathrm{L}}$ melatonin caused a significant decrease with respect to untreated cells (Fig. 9Ca, Da, Fa, and Ga) suggesting that melatonin may affect these channels functionality also in the process of differentiation.

\section{Discussion}

Different types of human cancers display a peculiar biophysical profile and/or atypical ionic channels activity. This is the reason why the role of ionic channels in the control of the cell cycle in normal and transformed cells has already been addressed by many research groups, in the attempt of identifying efficient targets for therapeutic approaches (Abdul et al., 2003; Arcangeli et al., 2009; Asher et al., 2010; Aydar et al., 2009; Becchetti, 2011; Currò, 2014; Wang, 2004). The detailed electrophysiological analysis performed in this study on MCF-7 cells adds new insights to the elucidation of the possible mechanisms involved in the oncostatic action of melatonin based on the cultured condition. Particularly, MCF-7 cells cultured for $72 \mathrm{~h}$ in growth medium had a reduced surface area, were more depolarized, and had a reduced $\mathrm{I}_{\mathrm{Ca}, \mathrm{T}}$ and $\mathrm{I}_{\mathrm{Ca}, \mathrm{L}}, \mathrm{a}$ greater $I_{\mathrm{Ks}}$ and a similar $I_{\mathrm{K}(\mathrm{V})}$ and $I_{\mathrm{BK}}$ current density respect to MCF-7 cells cultured in differentiation medium.

The increase of the membrane depolarization, of the membrane surface and of all the voltage-dependent $\mathrm{Ca}^{2+}$ and $\mathrm{K}^{+}$currents observed in the present study in control cells in growth medium suggests a progressive increase in the expression/activity of these channels along with culture time. This event can successfully maintain the proliferative potential of MCF-7 cells that is, one of the alarming features of the cancerous phenotype. When the cells were cultured in growth medium in the presence of melatonin, a significant reduction of proliferation and viability was observed as 
A

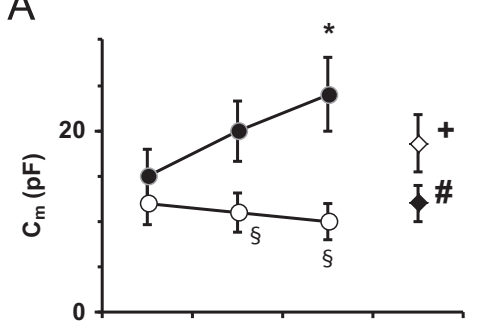

$\mathrm{Ca}$
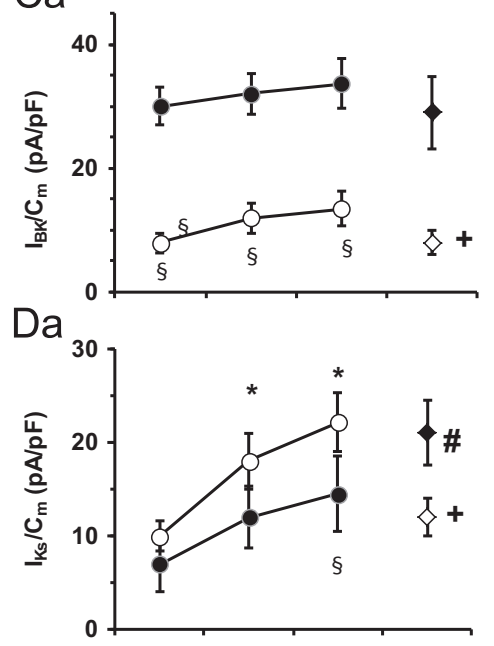

Ea

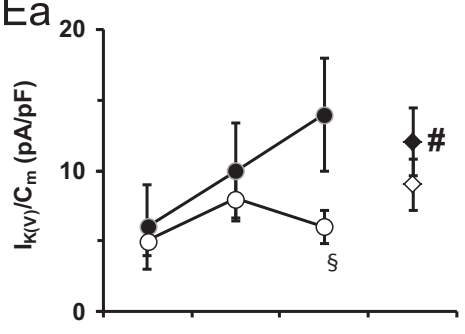

$\mathrm{Fa}$

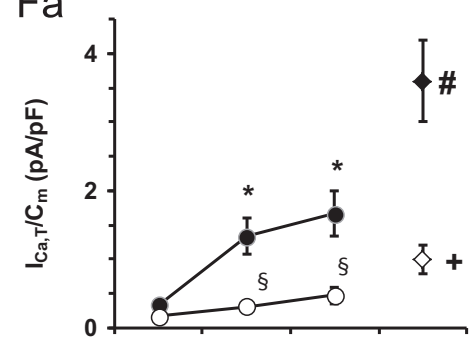

$\mathrm{Ga}$

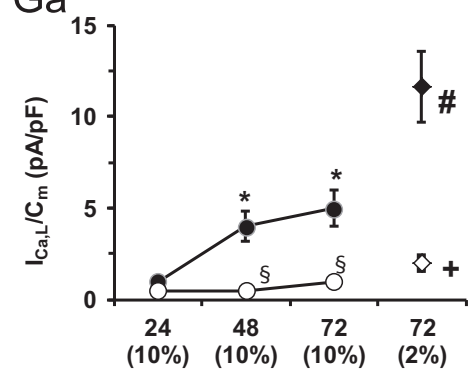

Time (h)

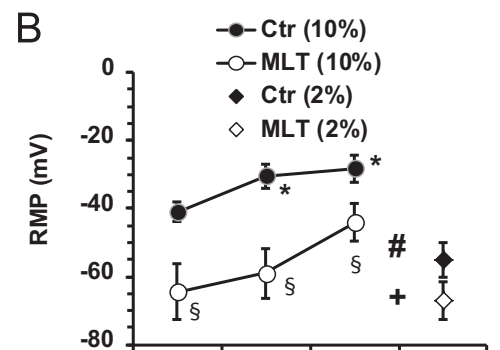

$\mathrm{Cb}$

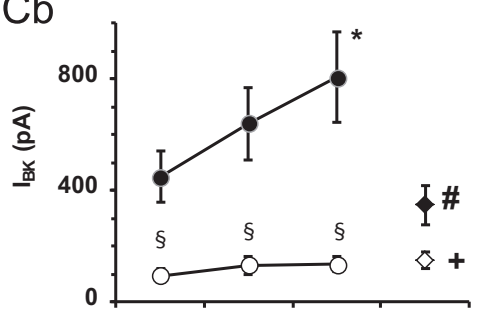

$\mathrm{Db}$

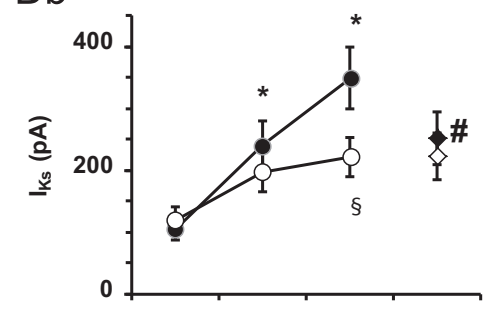

Eb

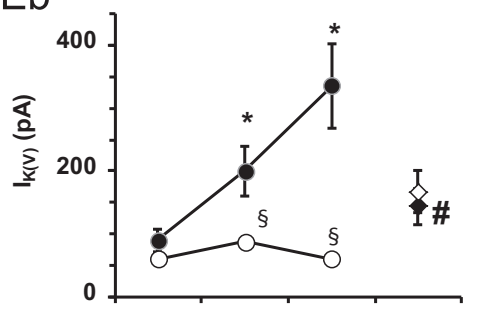

$\mathrm{Fb}$

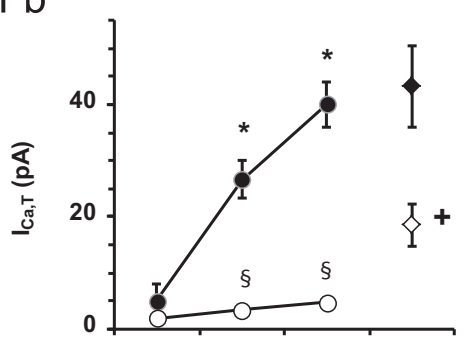

$\mathrm{Gb}$

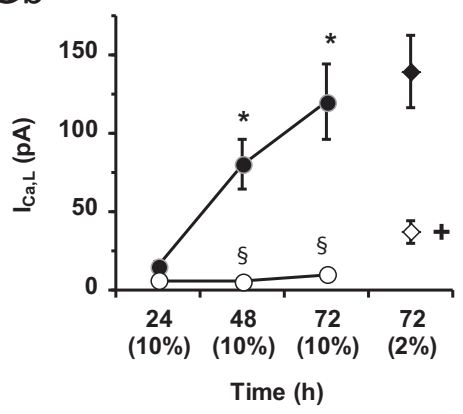

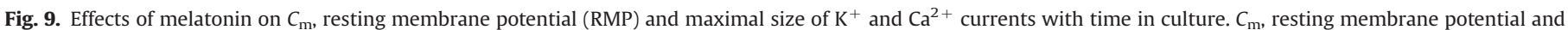

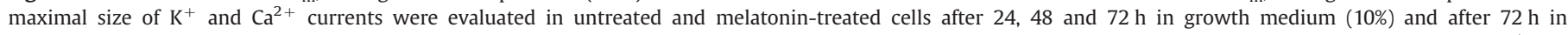

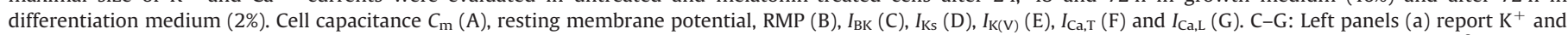

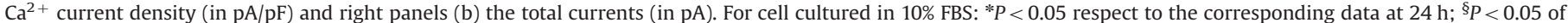

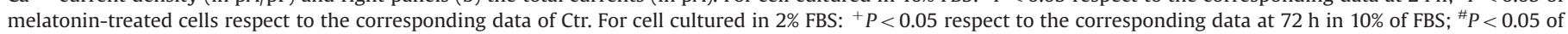

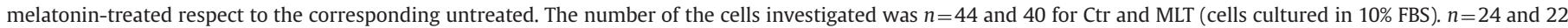
for Ctr and MLT (in 2\% FBS). 
compared to untreated ones. Actually, melatonin was able to reduce proliferation also in differentiating cells, but since this effect was less marked than that observed in cells cultured in growth medium a more effective action of melatonin on growth rather than on differentiation can be suggested. To verify this hypothesis the possible effects of melatonin on the different ion currents known to have a role in proliferation were tested.

In relation to $I_{\mathrm{Ca}}$, our findings demonstrate that melatonin treatment was able to reduce both $\mathrm{T}$ - and L-type $\mathrm{Ca}^{2+}$ current amplitude and to provoke an alteration of the current voltage dependence along with a decrease of intracellular $\mathrm{Ca}^{2+}$ concentration. Since $\mathrm{Ca}^{2+}$ seems to be a crucial regulator of the cell cycle necessary for proper proliferation (Bertolesi et al., 2002; Gray et al., 2004; Naziroğlu et al., 2012; Wang et al., 2000), the associated reduction of free $\left[\mathrm{Ca}^{2+}\right]_{\mathrm{i}}$ observed in our experiments supports the clue that melatonin may contribute to the decline of proliferation also disturbing internal $\mathrm{Ca}^{2+}$ homeostasis. The G-protein-coupled melatonin MT1 receptors are expressed in MCF-7 cells (Girgert et al., 2009; Hill et al., 2011b; Jablonska et al., 2013; Jawed et al., 2007; Rich et al., 1999) and, via the inhibition of adenylate cyclase activity (Jablonska et al., 2013; Jawed et al., 2007), their activation leads to the decrease of adenosine 3', 5'-cyclic monophosphate (cAMP) synthesis. Considering that in MCF-7 melatonin affected cell functionality by a significant depletion of ATP levels (Margheri et al., 2012), we propose that the decrease of cAMP, leading to a decrease of PKA activity and channel phosphorylation, can be considered a crucial mechanism involved in the reduction of L-and T-type $\mathrm{Ca}^{2+}$ currents (Mahapatra et al., 2012; Novara et al., 2004; Sundelacruz et al., 2009), further stressing the evidence that $\mathrm{Ca}^{2+}$ channels are a target by which melatonin can modulate cell proliferation.

Similarly, in this study we demonstrated that also $\mathrm{K}^{+}$currents are involved in the melatonin modulatory action of cell proliferation. Melatonin treatment caused a reduction in $I_{\mathrm{K}(\mathrm{V})}$ and $I_{\mathrm{BK}}$ but an increase of $I_{\mathrm{Ks}}$ density. MTS assay showed that melatonin decreased cell growth/viability in cells pre-treated with $\alpha$-DTX or with Chr. However, this reduction may not univocally depend only on $\mathrm{K}(\mathrm{v})$ or Ks channels, because even if such channels are blocked, melatonin can still exert its effect of reducing cell proliferation/viability through a pathway involving $I_{\mathrm{BK}}$. BK channel activation requires $\mathrm{Ca}^{2+}$ entry which, in turn, activates BK channels located in close vicinity to the $\mathrm{Ca}^{2+}$ source (Berkefeld et al., 2006; Marcantoni et al., 2010). According to Berkefeld et al. (2006) and Marcantoni et al. (2010), our results on $I_{\mathrm{BK}}$ could be explained suggesting that melatonin was able to cause the shift of BK channels far from L-type $\mathrm{Ca}^{2+}$ channels, leading to the impairment of BK channels assembly and functionality and thus to the reduction of $I_{\mathrm{BK}}$ and its kinetics.

The depolarization of resting membrane potential is usually detected in proliferating cells and, since there is a clear correlation between resting membrane potential and mitotic activity, it is obvious that the maintenance of a proper membrane potential during cell cycling, mainly controlled by $\mathrm{K}^{+}$channels (Klimatcheva and Wonderlin, 1999), is of primary importance. The mean resting membrane potential values recorded in MCF-7 cells were quite depolarized, as typically observed in cancer cells with respect to that of terminally differentiated cells (Sundelacruz et al., 2009) and tended to depolarize further with time in culture. Whatever the mechanism underlying the establishment and the maintenance of resting membrane potential in cells cultured in growth medium, it can be affirmed that melatonin was capable to hyperpolarize the resting membrane potential which, conversely tended to depolarize with time in control condition. The hyperpolarization induced by melatonin can be partly justified by the L-type $\mathrm{Ca}^{2+}$ current decrease in amplitude, the increase of $\left[\mathrm{Ca}^{2+}\right]_{\mathrm{i}}$ and of $\mathrm{I}_{\mathrm{Ks}}$ density.

However, to elucidate this issue, it must be considered that besides the voltage dependent ion channel activation, many other mechanisms may contribute to the establishment of resting membrane potential, such as stretch activated channels (Aydar et al., 2009; Formigli et al., 2007; Sbrana et al., 2008), ionic pumps (2Na/3 K ATPase and $\mathrm{Ca}^{2+}$ pump), 3Na/Ca exchanger (Becchetti 2011) and voltage-independent channels as IKCa and $\mathrm{K}_{\text {ATP }}$ (Abdul et al., 2003; Blackiston et al., 2009; Haren et al., 2010; Klimatcheva and Wonderlin, 1999), and that the complexity of the scenario requires further investigations.

Moreover, melatonin reduced the increase of $C_{\mathrm{m}}$ that is usually observed in untreated-cells with time in culture. Therefore, we suggest that the increase of cell membrane surface area usually observed in control proliferating cells was definitely inhibited by melatonin, this effect being specifically addressed to cells in proliferation. In fact, when cells were cultured in differentiation medium, melatonin caused an increase in $C_{\mathrm{m}}$. Moreover, data obtained by MTS assay showed that melatonin had a lower effect in reducing growth/ viability in cells cultured in differentiation with respect to growth medium. Consequently, melatonin action differed according to the culture media and associated proliferation rate.

\section{Conclusions}

Our research shows that the alteration in ion channel gating may be considered as a final effector of the action of melatonin on cell proliferation. Even if this is just an in vitro study, it extends and provides novel experimental evidence related to the melatonin oncostatic action. In fact, the present findings indicate that melatonin is able to counteract proliferation as well as differentiation in MCF-7 cell line. This result strongly indicates that melatonin, as a modulator of different voltage-dependent ion channels, might act as a new promising tool for specifically disrupting cell viability and differentiation pathway in tumour cells and consequently may be potentially helpful in cancer therapy.

\section{Acknowledgments}

This paper is dedicated to the dear memory of Lucia Formigli who has passed away on March 18th, 2014. The authors wish to thank Dr D. Nosi for his valuable assistance in $\mathrm{Ca}^{2+}$ imaging experiments. This study was supported by LOGO-BIOS, O.N.L.U.S. Foundation 20100-m3810.

\section{References}

Abdul, M., Santo, A., Hoosein, N., 2003. Activity of potassium channel-blockers in breast cancer. Anticancer Res. 23, 347-351.

Arcangeli, A., Crociani, O., Lastraioli, E., Masi, A., Pillozzi, S., Becchetti, A., 2009. Targeting ion channels in cancer: a novel frontier in antineoplastic therapy. Curr. Med. Chem. 16, 66-93.

Asher, V., Sowter, H., Shaw, R., Bali, A., Khan, R., 2010. Eag and HERG potassium channels as novel therapeutic targets in cancer. World J. Surg. Oncol. 29, $113-117$.

Aydar, E., Yeo, S., Djamgoz, M., Palmer, C., 2009. Abnormal expression, localization and interaction of canonical transient receptor potential ion channels in human breast cancer cell lines and tissues: a potential target for breast cancer diagnosis and therapy. Cancer Cell Int. 18, 9-23.

Baglioni, S., Francalanci, M., Squecco, R., Lombardi, A., Cantini, G., Angeli, R., Gelmini, S., Guasti, D., Benvenuti, S., Annunziato, F., Bani, D., Liotta, F., Francini, F., Perigli, G., 2009. Characterization of human adult stem cell population isolated from visceral and subcutaneous adipose tissue. FASEB J. 23, 3494-3505.

Baglioni, S., Cantini, G., Poli, G., Francalanci, M., Squecco, R., Di Franco, A., Borgogni, E., Frontera, S., Nesi, G., Liotta, F., Lucchese, M., Perigli, G., Francini, F., Forti, G., Serio, M., Luconi, M., 2012. Functional differences in visceral and subcutaneous fat pads originate from differences in the adipose stem cell. PLoS One 7, e36569.

Becchetti, A., 2011. Ion channels and transporters in cancer. 1. Ion channels and cell proliferation in cancer. Am. J. Physiol. Cell. Physiol. 301, C255-C265.

Berkefeld, H., Sailer, C.A., Bildl, W., Rohde, V., Thumfart, J.O., Eble, S., Klugbauer, N., Reisinger, E., Bischofberger, J., Oliver, D., Knaus, H.G., Schulte, U., Fakler, B., 2006. BKCa-Cav channel complexes mediate rapid and localized $\mathrm{Ca}^{2+}$-activated $\mathrm{K}^{+}$signaling. Science 314, 615-620. 
Bertolesi, G.E., Shi, C., Elbaum, L., Jollimore, C., Rozenberg, G., Barnes, S., Kelly, M.E., 2002. The $\mathrm{Ca}^{2+}$ channel antagonists mibefradil and pimozide inhibit cell growth via different cytotoxic mechanisms. Mol. Pharmacol. 62, 210-219.

Bielanska, J., Hernández-Losa, J., Pérez-Verdaguer, M., Moline, T., Somoza, R., Ramón y Cajal, S., Condom, E., Ferreres, J.C., Felipe, A., 2009. Voltage-dependent potassium channels Kv1.3 and Kv1.5 in human cancer. Curr. Cancer Drug Targets 9, 904-914.

Blackiston, D.J., McLaughlin, K.A., Levin, M., 2009. Bioelectric controls of cell proliferation: ion channels, membrane voltage and the cell cycle. Cell Cycle 8, 3519-3528.

Cos, S., Sánchez-Barceló, E.J., 2003. Melatonin and mammary pathological growth. Front. Neuroendocrinol. 21, 133-170.

Currò, D., 2014. $\mathrm{K}^{+}$channels as potential targets for the treatment of gastrointestinal motor disorders. Eur. J. Pharmacol. 733, 97-101.

Enomoto, K., Cossu, M.F., Maeno, T., Edwards, C., Oka, T., 1986. Involvement of the $\mathrm{Ca}^{2+}$-dependent $\mathrm{K}^{+}$channel activity in the hyperpolarizing response induced by epidermal growth factor in mammary epithelial cells. FEBS Lett. 203, 181-184.

Formigli, L., Francini, F., Meacci, E., Vassalli, M., Nosi, D., Quercioli, F., Tiribilli, B., Bencini, C., Piperio, C., Bruni, P., Orlandini, S.Z., 2002. Sphingosine 1-phosphate induces $\mathrm{Ca}^{2+}$ transients and cytoskeletal rearrangement in $\mathrm{C} 2 \mathrm{C} 12$ myoblastic cells. Am. J. Physiol. Cell Physiol. 282, C1361-C1373.

Formigli, L., Meacci, E., Sassoli, C., Squecco, R., Nosi, D., Chellini, F., Naro, F., Francini, F., Zecchi-Orlandini, S., 2007. Cytoskeleton/stretch-activated ion channel interaction regulates myogenic differentiation of skeletal myoblasts. J. Cell. Physiol. 211, 296-306.

Gamper, N., Fillon, S., Huber, S.M., Feng, Y., Kobayashi, T., Cohen, P., Lang, F., 2002. IGF-1 up-regulates $\mathrm{K}+$ channels via PI3-kinase, PDK1 and SGK1. Pflug. Arch. $443,625-634$

Girgert, R., Hanf, V., Emons, G., GrÜndker, C., 2009. Membrane-bound melatonin receptor MT1 down-regulates estrogen responsive genes in breast cancer cells. J. Pineal Res. 47, 23-31.

Grant, S.G., Melan, M.A., Latimer, J.J., Witt-Enderby, P.A., 2009. Melatonin and breast cancer: cellular mechanisms, clinical studies and future perspectives. Expert Rev. Mol. Med. 11, e5. http://dx.doi.org/10.1017/S1462399409000982.

Gray, L.S., Perez-Reyes, E., Gomora, J.C., Haverstick, D.M., Shattock, M., McLatchie, L., Harper, J., Brooks, G., Heady, T., Macdonald, T.L., 2004. The role of voltage gated T-type $\mathrm{Ca}^{2+}$ channel isoforms in mediating "capacitative" $\mathrm{Ca}^{2+}$ entry in cancer cells. Cell Calcium 36, 489-497.

Haren, N., Khorsi, H., Faouzi, M., Ahidouch, A., Sevestre, H., Ouadid-Ahidouch, H., 2010. Intermediate conductance $\mathrm{Ca}^{2+}$ activated $\mathrm{K}^{+}$channels are expressed and functional in breast adenocarcinomas: correlation with tumour grade and metastasis status. Histol. Histopathol. 25, 1247-1255.

Hill, S.M., Blask, D.E., Xiang, S., 2011a. Melatonin and associated signaling pathways that control normal breast epithelium and breast cancer. J. Mammary Gland Biol. Neoplasia 16, 235-245.

Hill, S.M., Cheng, C., Yuan, L., Mao, L., Jockers, R., Dauchy, B., Frasch, T., Blask, D.E., 2011b. Declining melatonin levels and MT1 receptor expression in aging rats is associated with enhanced mammary tumor growth and decreased sensitivity to melatonin. Breast Cancer Res. Treat. 127, 91-98.

Hill, S.M., Frasch, T., Xiang, S., Yuan, L., Duplessis, T., Mao, L., 2009. Molecular mechanisms of melatonin anticancer effects. Integr. Cancer Ther. 8, 337-346.

Jablonska, K., Pula, B., Zemla, A., Owczarek, T., Wojnar, A., Rys, J., Ambicka, A., Podhorska-Okolow, M., Ugorski, M., Dziegiel, P., 2013. Expression of melatonin receptor MT1 in cells of human invasive ductal breast carcinoma. J. Pineal Res. 54, 334-345.

Jawed, S., Kim, B., Ottenhof, T., Brown, G.M., Werstiuk, E.S., Niles, L.P., 2007. Human melatonin MT1 receptor induction by valproic acid and its effects in combination with melatonin on MCF-7 breast cancer cell proliferation. Eur. J. Pharmacol. 560, 17-22.

Jung, B., Ahmad, N., 2006. Melatonin in cancer management: progress and promise. Cancer Res. 66, 9789-9793.
Klimatcheva, E., Wonderlin, W.F., 1999. An ATP-sensitive $\mathrm{K}(+)$ current that regulates progression through early Gl phase of the cell cycle in MCF-7 human breast cancer cells. J. Membr. Biol. 171, 35-46.

Kunzelmann, K., 2005. Ion channels and cancer. J. Membr. Biol. 205, 159-173.

Lang, F., Henke, G., Embark, H.M., Waldegger, S., Palmada, M., Bohmer, C., Vallon, V., 2003. Regulation of channels by the serum and glucocorticoid-inducible kinase - implications for transport, excitability and cell proliferation. Cell. Physiol. Biochem. 13, 41-50.

Mahapatra, S., Marcantoni, A., Zuccotti, A., Carabelli, V., Carbone, E., 2012. Equa sensitivity of Cav1.2 and Cav1.3 channels to the opposing modulations of PKA and PKG in mouse chromaffin cells. J. Physiol. 590, 5053-5073.

Marcantoni, A., Vandael, D.H., Mahapatra, S., Carabelli, V., Sinnegger-Brauns, M.J. Striessnig, J., Carbone, E., 2010. Loss of Cav1.3 channels reveals the critical role of L-type and BK channel coupling in pacemaking mouse adrenal chromaffin cells. J. Neurosci. 30, 491-504.

Margheri, M., Pacini, N., Tani, A., Nosi, D., Squecco, R., Dama, A., Masala, E., Francini, F., Zecchi-Orlandini, S., Formigli, L., 2012. Combined effects of melatonin and all-trans retinoic acid and somatostatin on breast cancer cell proliferation and death: molecular basis for the anticancer effect of these molecules. Eur J. Pharmacol. 681, 34-43.

Naziroğlu, M., Tokat, S., Demirci, S., 2012. Role of melatonin on electromagnetic radiation-induced oxidative stress and $\mathrm{Ca}^{2+}$ signaling molecular pathways in breast cancer. J. Recept. Signal Transduct. Res. 32, 290-297.

Novara, M., Baldelli, P., Cavallari, D., Carabelli, V., Giancippoli, A., Carbone, E., 2004 Exposure to cAMP and $\beta$-adrenergic stimulation recruits CaV3 T-type channels in rat chromaffin cells through Epac cAMP-receptor proteins. J. Physiol. 558, 433-449.

O’Grady, S.M., Lee, S.Y., 2005. Molecular diversity and function of voltage-gated (Kv) potassium channels in epithelial cells. Int. J. Biochem. Cell Biol. 37, 1578-1594.

Ohkubo, T., Yamazaki, J., 2012. T-type voltage-activated calcium channel Cav3.1, but not Cav3.2, is involved in the inhibition of proliferation and apoptosis in MCF-7 human breast cancer cells. Int. J. Oncol. 41, 267-275.

Ouadid-Ahidouch, H., Ahidouch, A., 2008. $\mathrm{K}^{+}$channel expression in human breast cancer cells: involvement in cell cycle regulation and carcinogenesis. J. Membr. Biol. 221, 1-6.

Pardo, L.A., 2004. Voltage-gated potassium channels in cell proliferation. J. Physiol 19, 285-292.

Prakriya, M., Lingle, C.J., 1999. BK channel activation by brief depolarizations requires $\mathrm{Ca}^{2+}$ influx through $\mathrm{L}-$ and $\mathrm{Q}$-type $\mathrm{Ca}^{2+}$ channels in rat chromaffin cells. J. Neurophysiol. 81, 2267-2278.

Rich, A. Farrugia, G., Rae, J.L., 1999. Effects of melatonin on ionic currents in cultured ocular tissues. Am. J. Physiol. 276, C923-C929.

Sánchez-Barceló, E.J., Mediavilla, M.D., Alonso-Gonzalez, C., Rueda, N., 2012. Breast cancer therapy based on melatonin. Recent Pat. Endocr. Metab. Immune Drug Discov. 6, 108-116.

Sbrana, F., Sassoli, C., Nosi, D., Squecco, R., Paternostro, F., Tiribilli, B., ZecchiOrlandini, S., Francini, F., Formigli, L., 2008. Role for stress fiber contraction in surface tension development and stretch-activated channel regulation in C2C12 myoblasts. Am. J. Physiol. Cell Physiol. 295, 160-172.

Srinivasan, V., Spence, D.W., Pandi-Perumal, S.R., Trakht, I., Cardinali, D.P., 2008 Therapeutic actions of melatonin in cancer: possible mechanisms. Integr. Cancer Ther. 7, 189-203.

Sundelacruz, S., Levin, M., Kaplan, D.L., 2009. Role of membrane potential in the regulation of cell proliferation and differentiation. Stem Cell Rev. 5, 231-246.

Vijayalaxmi, T.C.R., Reiter, R.J., Herman, T.S., 2002. Melatonin: from basic research to cancer treatment clinics. J. Clin. Oncol. 20, 2575-2601.

Wang, Z., 2004. Roles of $\mathrm{K}(+)$ channels in regulating tumour cell proliferation and apoptosis. Pflug. Arch. 448, 274-286.

Wang, X.T., Nagaba, Y., Cross, H.S., Wrba, F., Zhang, L., Guggino, S.E., 2000. The mRNA of L-type calcium channel elevated in colon cancer: protein distribution in normal and cancerous colon. Am. J. Pathol. 157, 1549-1562. 